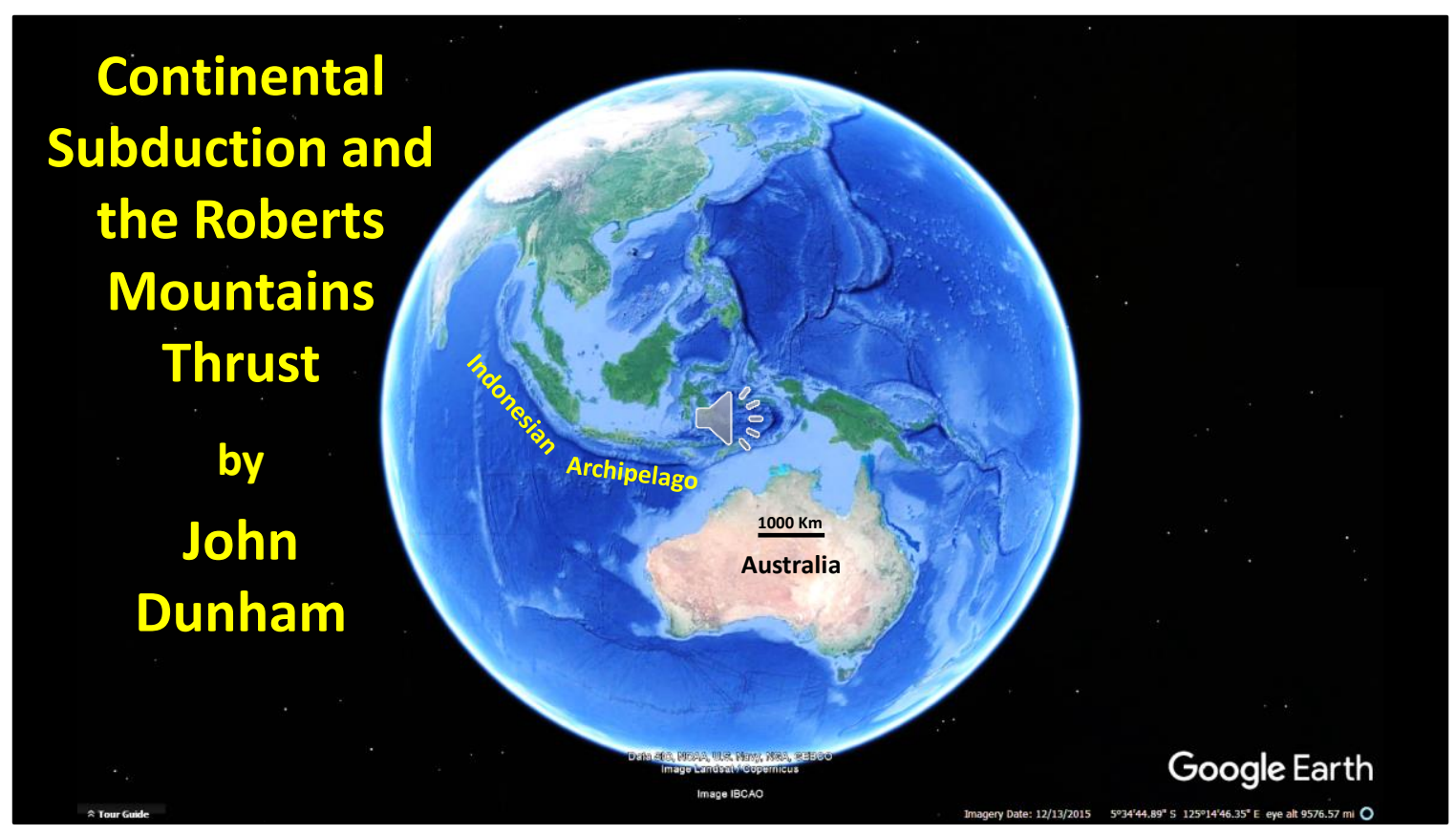

I started work at the Union Oil Company research lab in 1978. One of the best things about industry is that you get to see a lot of different projects, like this one that I worked on in Indonesia. 


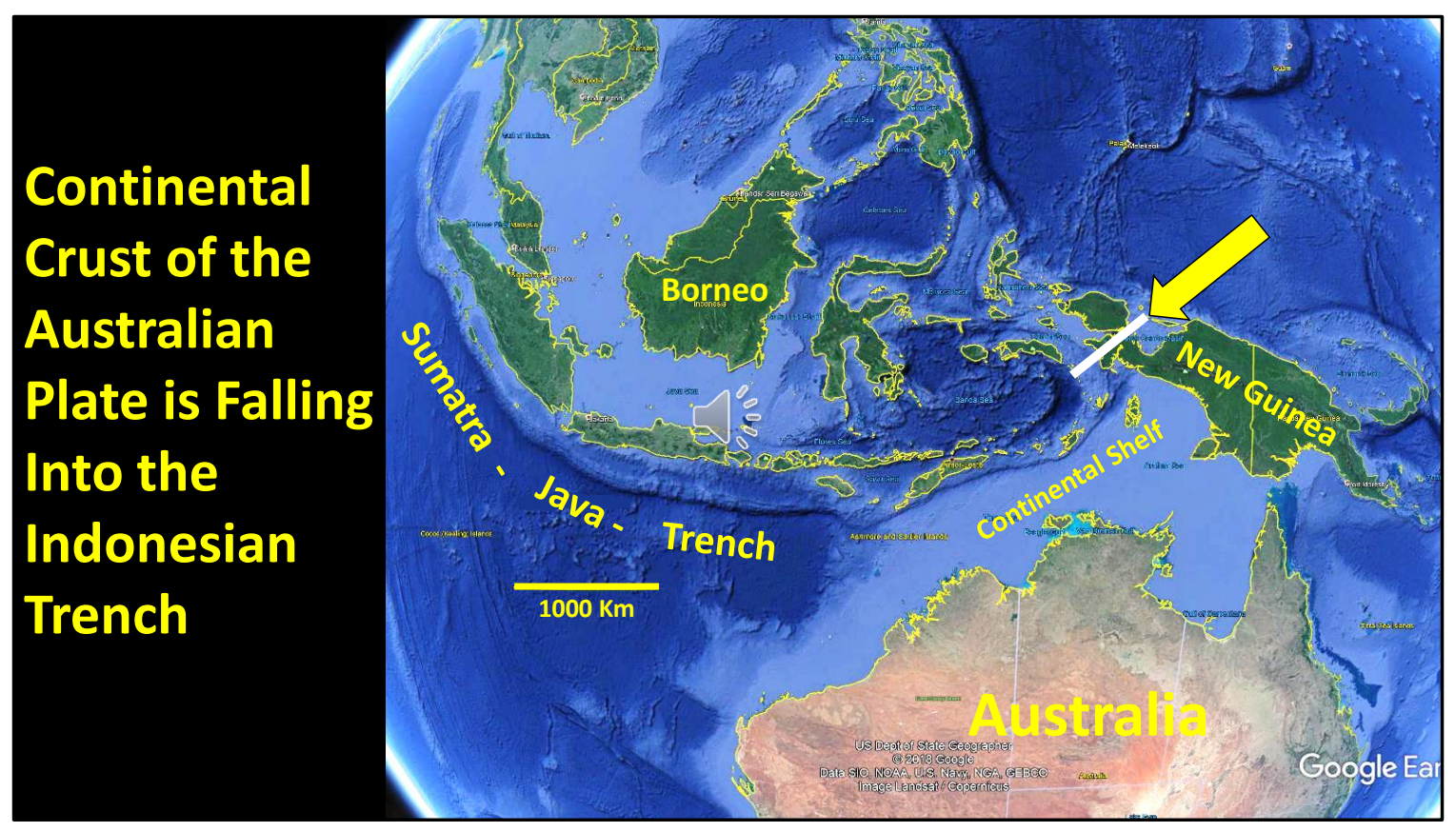

Specifically, I was looking at a prospect on the Western tip of New Guinea, where continental crust of the Australian plate is falling into the Eastern Indonesian subduction zone. The following slide is a seismic section along the line shown by the arrow. 


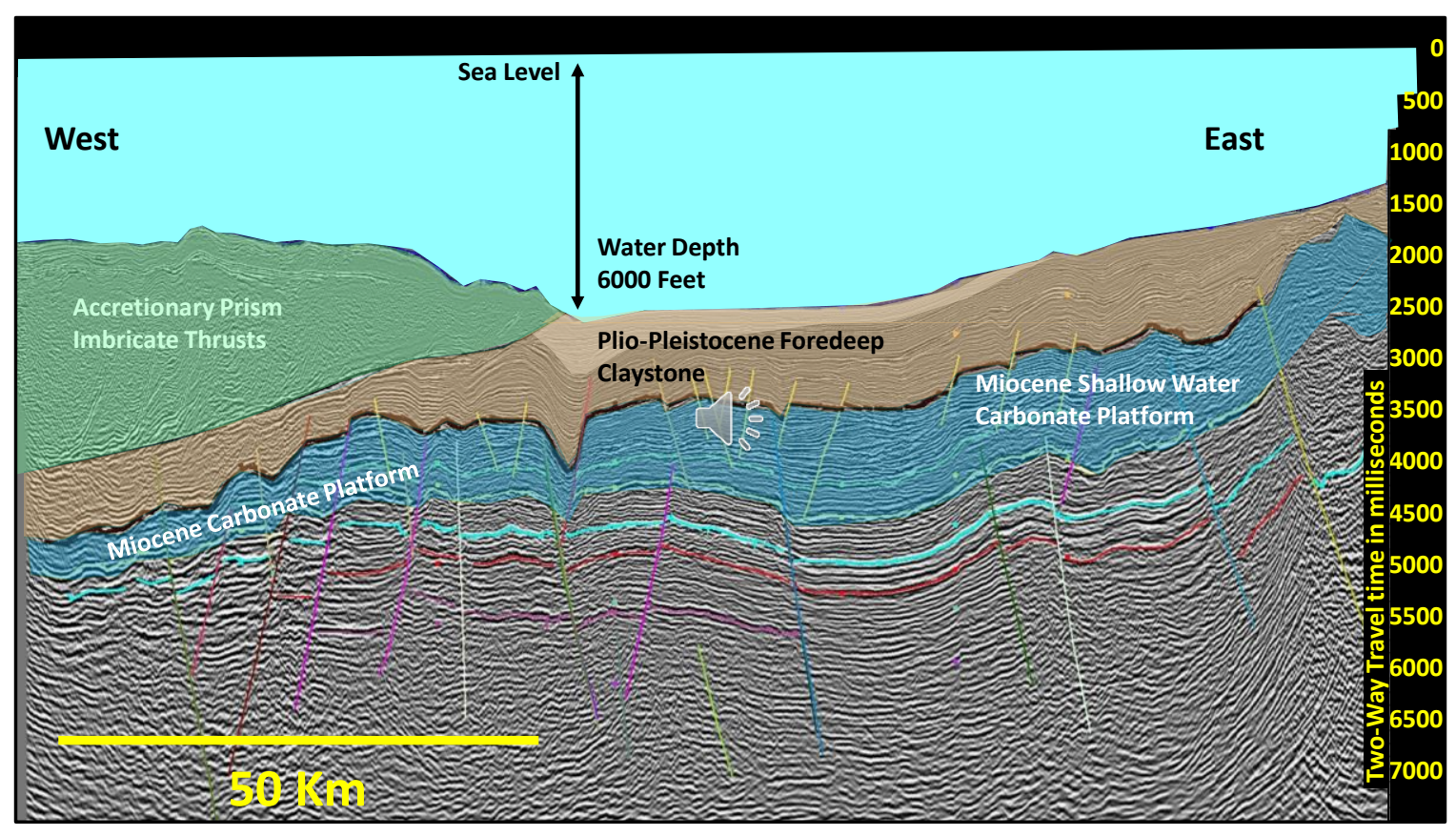

Data from exploration wells establish that a Miocene shallow water carbonate platform is falling into the Banda Arc subduction zone. A detachment surface separates the subducting lower plate from an overlying accretionary prism of sediment that was scraped off the top of the descending plate. The Miocene carbonates were deposited in shallow water, but as subsidence accelerated in Pliocene time due to descent into the trench, the carbonate platform stopped growing due to drowning, and became overlain by deep-water Plio-Pleistocene mudstones. 


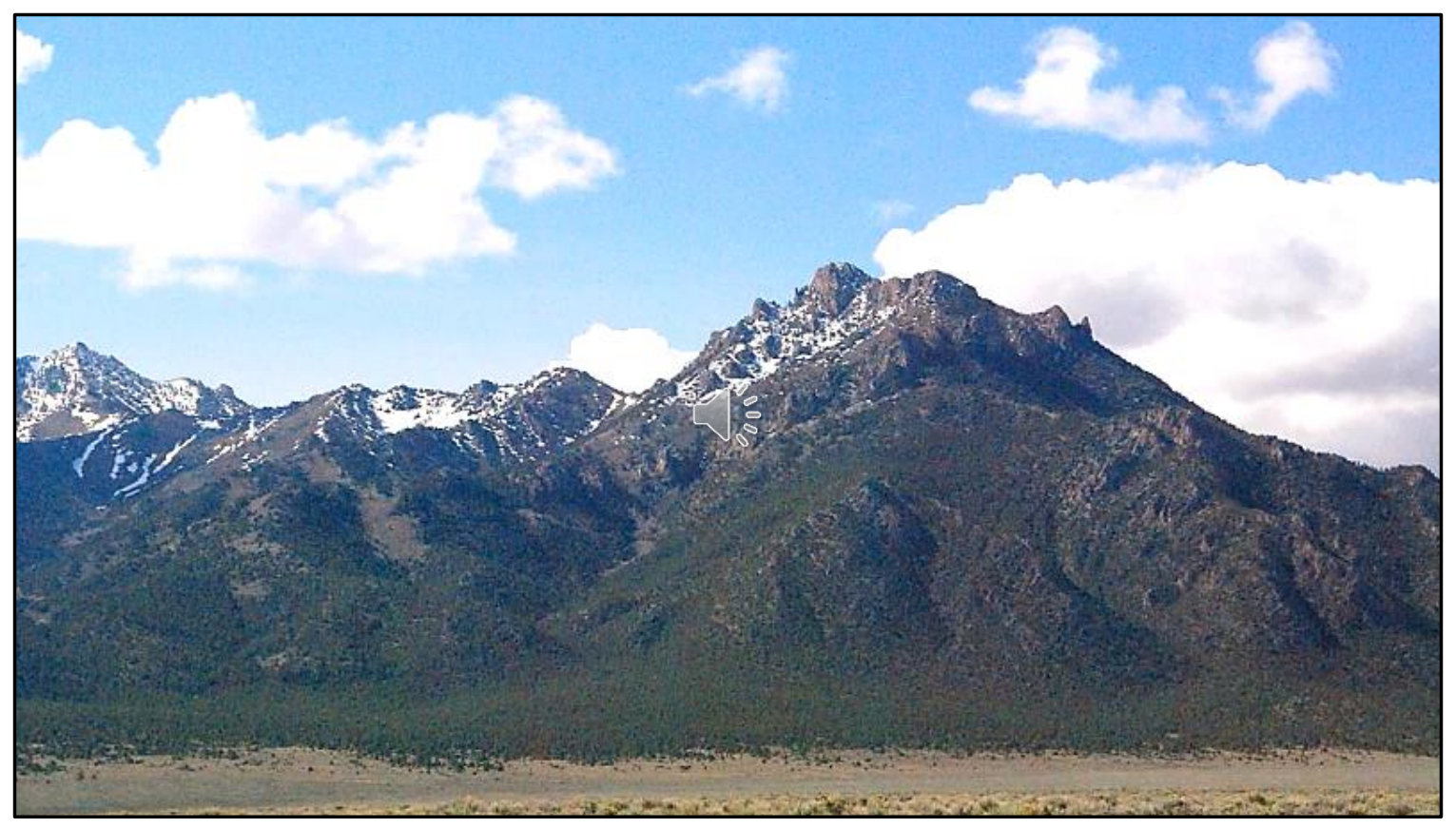

As soon as I saw that seismic line, I knew that I had seen it before; here, in the Roberts Mountains. Analogs are important to exploration geologists. The more different things you see, the more ideas you're likely to come up with. It's hard to visualize the concept of continental subduction without seeing examples of it, so l'll take you to the northwest shelf of Australia to let you see for yourselves. 


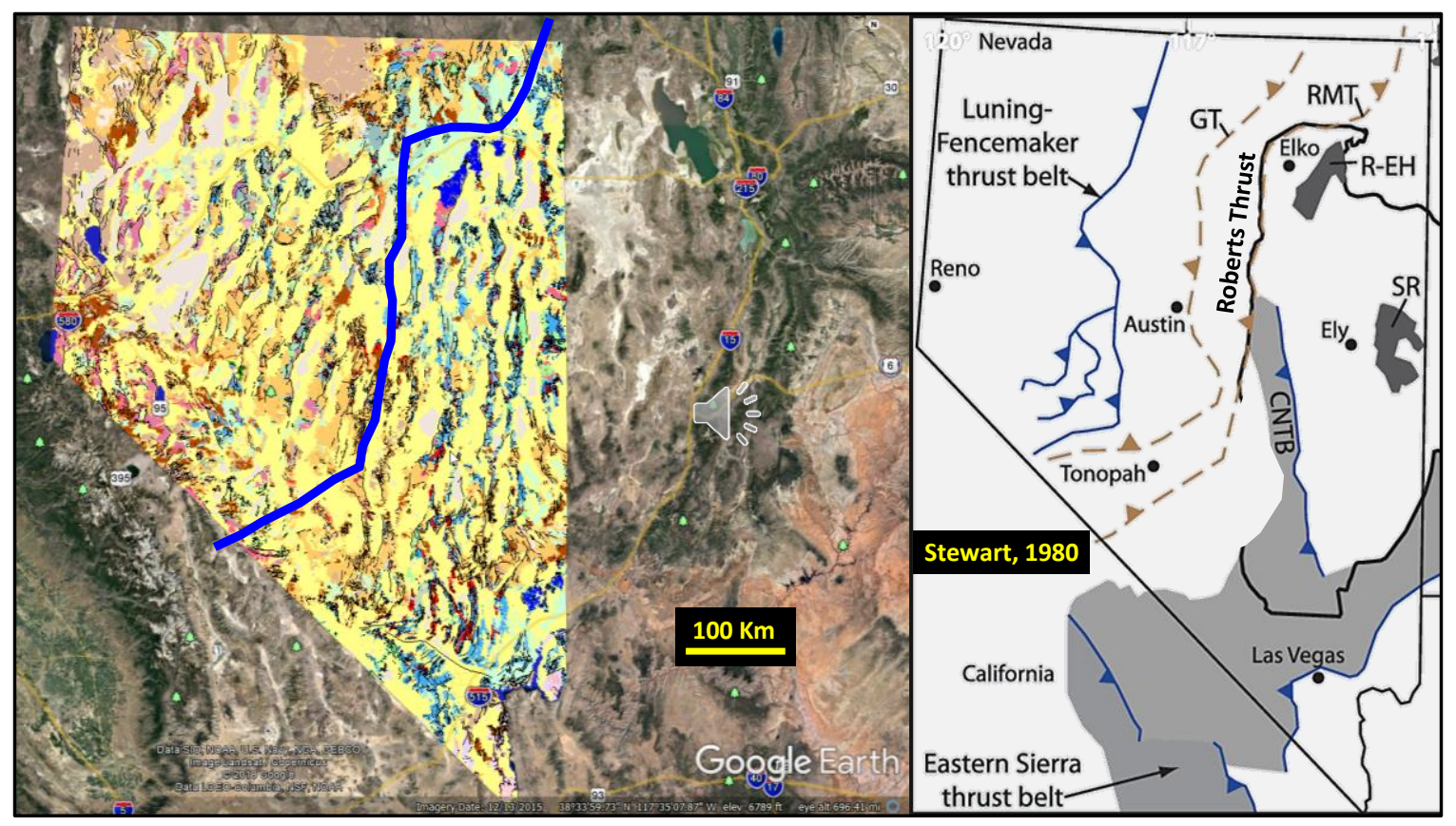

I'll start my presentation by taking a high-level view of the extent of the Roberts Mountains Thrust. The map on the right is from John Stewart's Geology of Nevada Volume and the map on the left is Stewart's geologic map of Nevada projected onto a Google Earth Image. The heavy blue line is the trace of the Roberts Mountains Thrust. I use Google Earth because it facilitates same-scale comparisons to other regions of the Earth as shown by the following slides. 


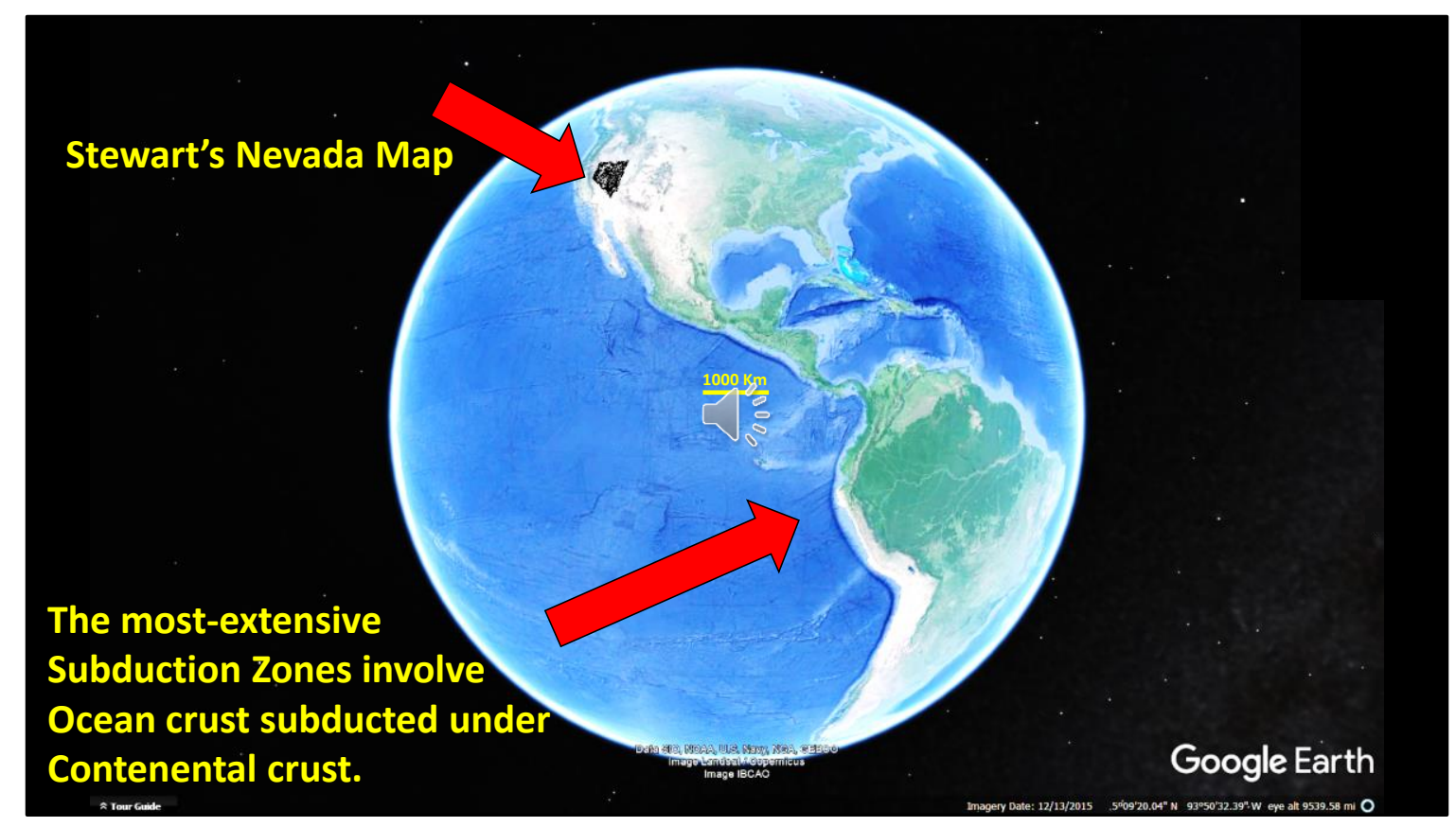

Stewart's Nevada Map is compared at a global scale to one of the most extensive subduction zones on earth, along the south and central American coasts. This is the most familiar type of subduction zone to most people, where oceanic crust is subducted under continental crust. 


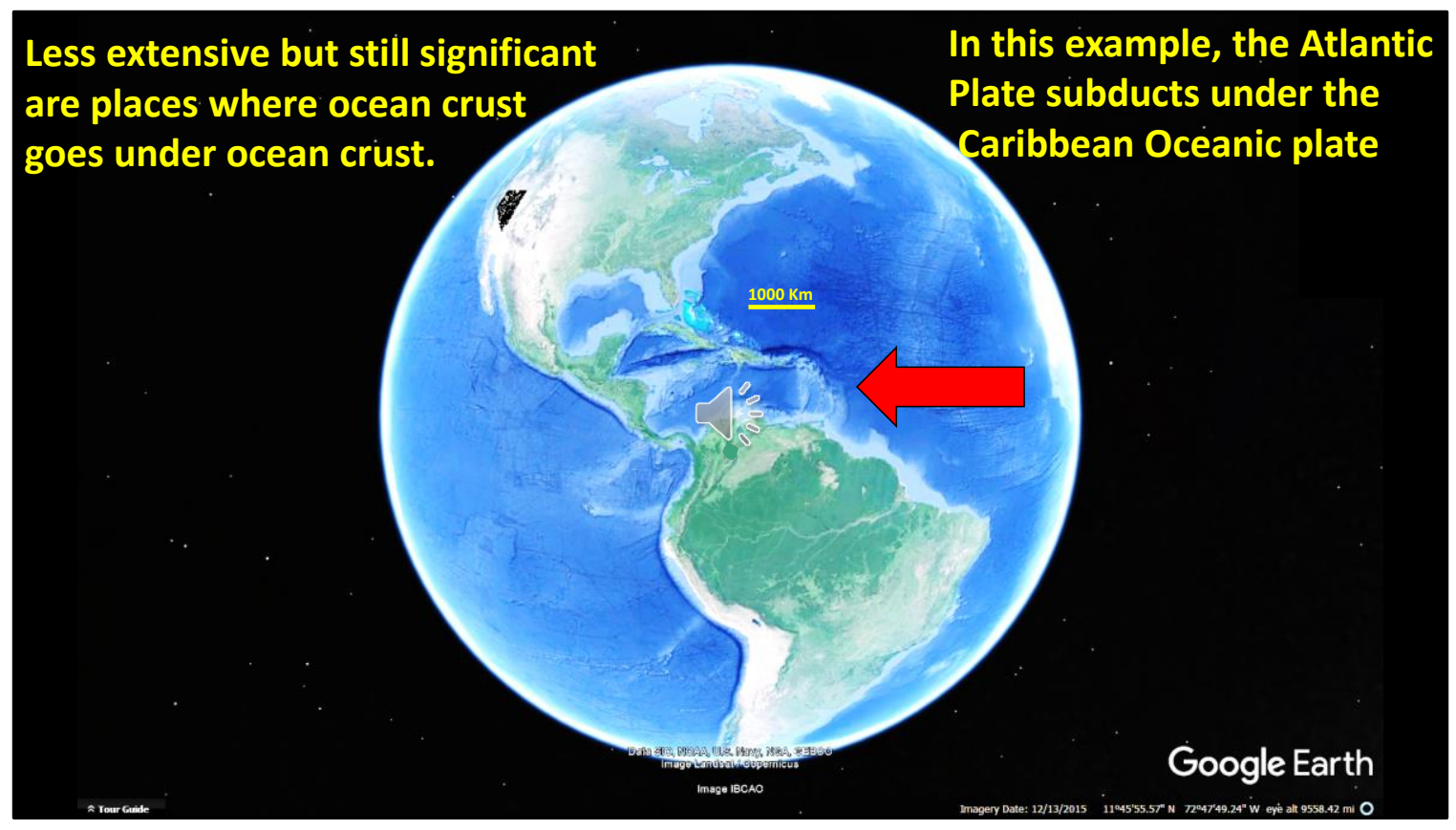

Several less extensive subduction zones are present where oceanic curst is subducted beneath a different plate of ocean crust. In this example, the Atlantic oceanic-crust subducts beneath the Caribbean oceanic-crust at a trench east of the Lesser Antilles Island Arc. 


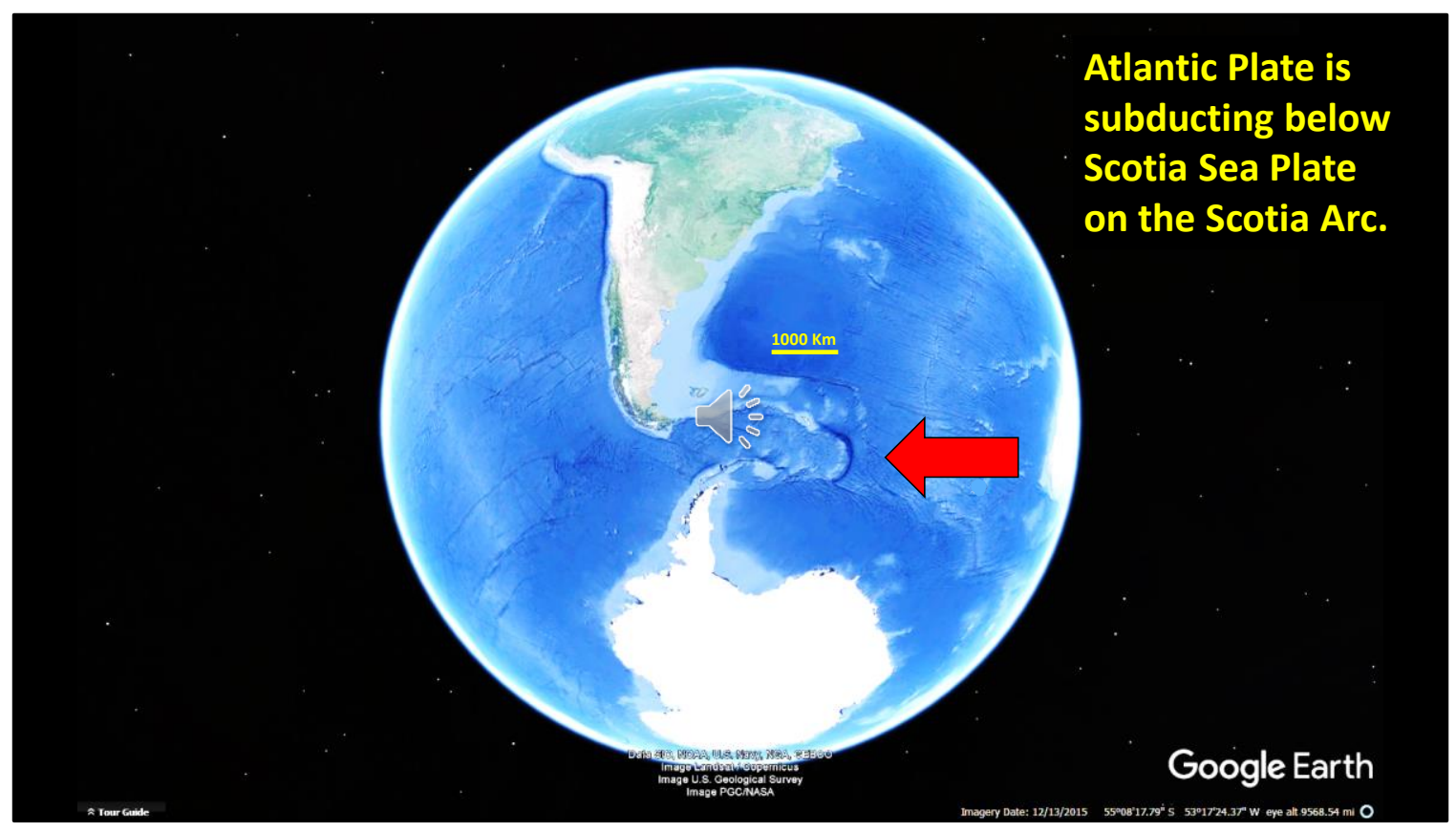

Another example where Atlantic crust subducts below the Scotia Sea Plate on the Scotia Arc. 


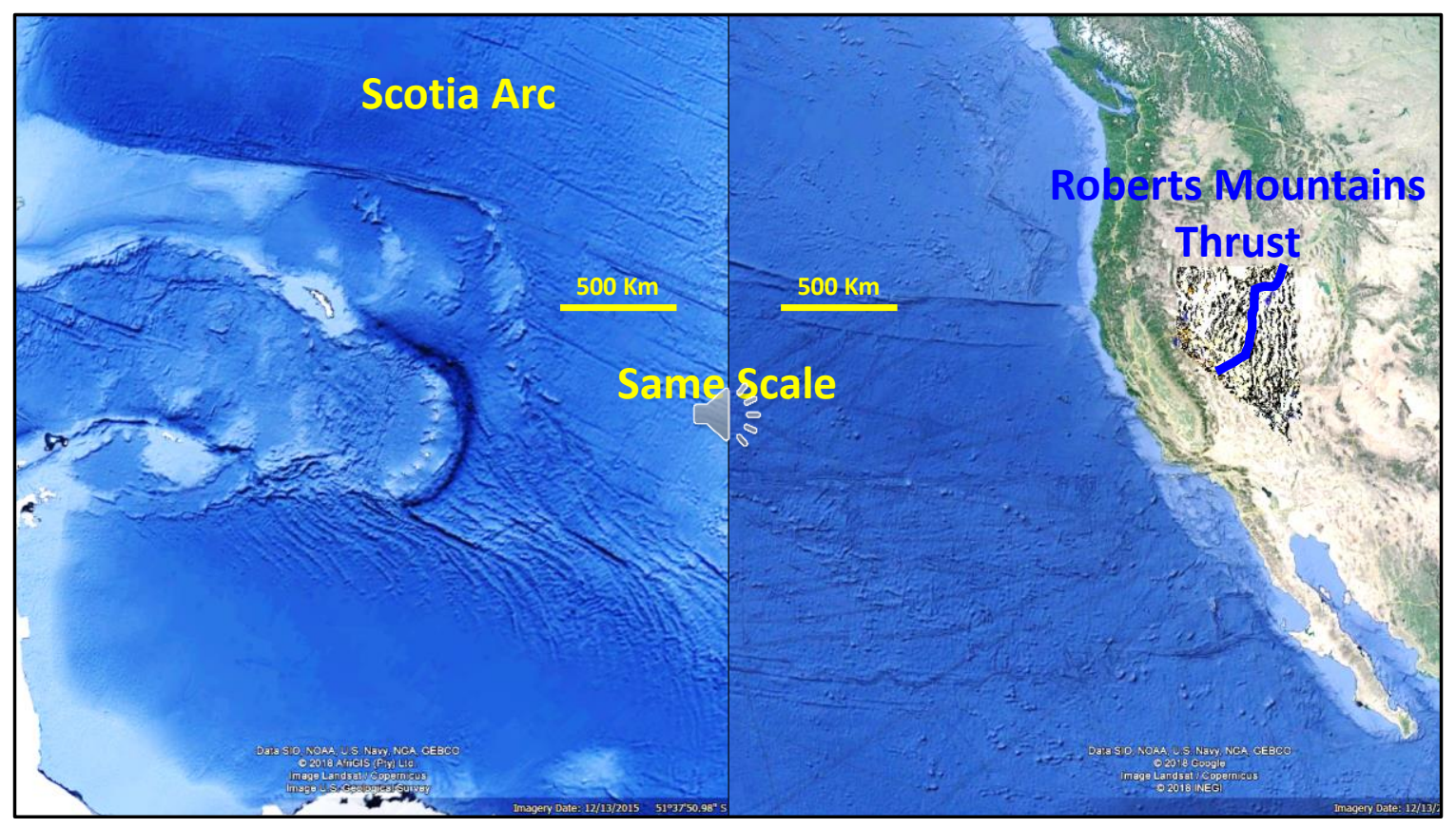

All the previous slides were a set up for this one. A comparison of the extent of the Scotia Arc to the Roberts Mountains, at the same scale. 


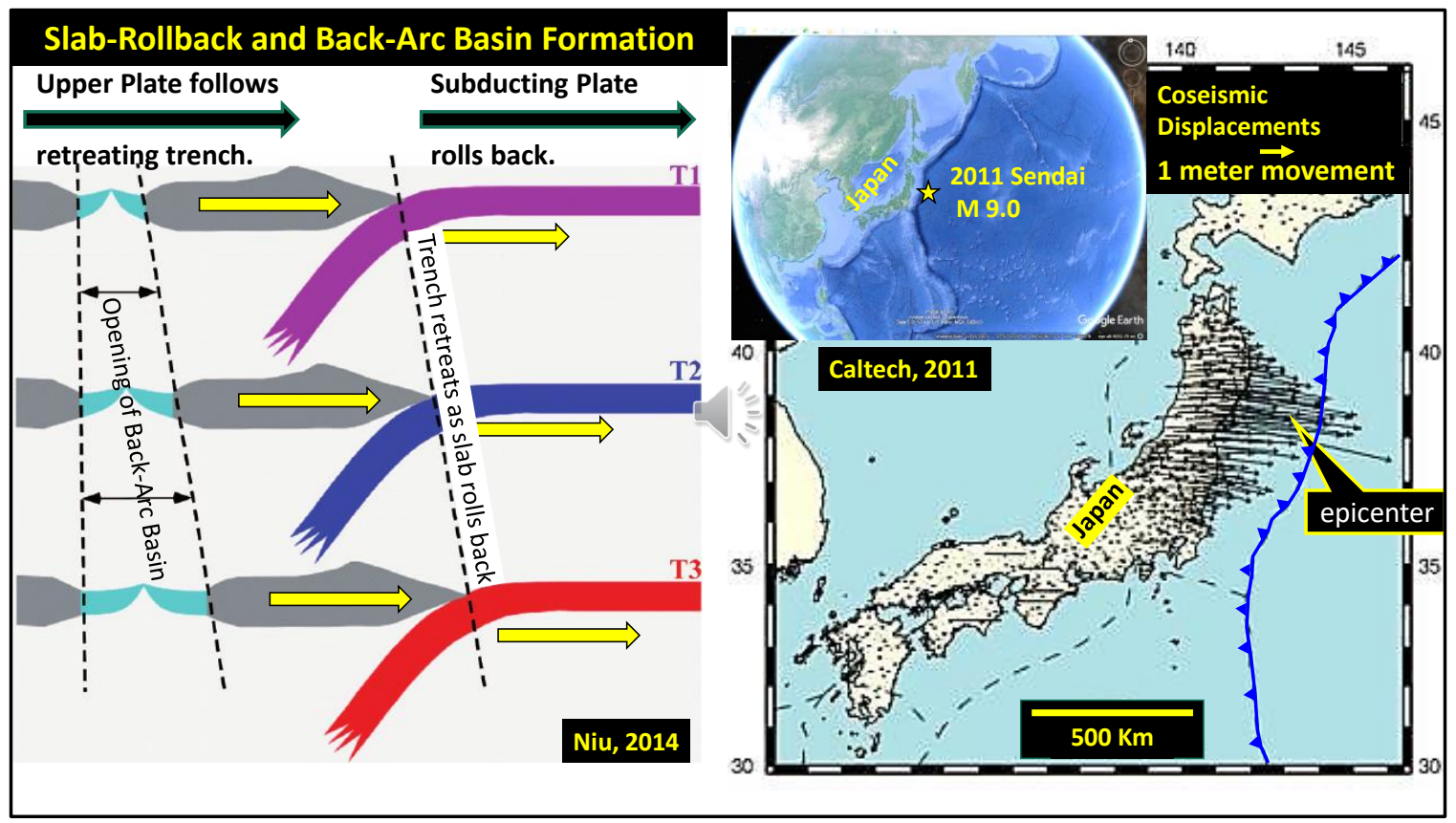

Oceanic Trenches physically move across the surface of the earth through the process of Slab Rollback. The hinge line of the subducting plate will move backward away from the trench over time. The map on the right shows GPS ground motion measurements following the magnitude 9 Sendai Earthquake of Japan. The earthquake occurred when the upper and lower plates of the subduction zone detached. The hinge line of the descending slab moved eastward, and at the same time the overlying plate moved eastward instantaneously for distances up to 10 meters to take up the space left by the slab-rollback process. These oceanic island arcs are moving across the surface of the earth over geological time scales. 


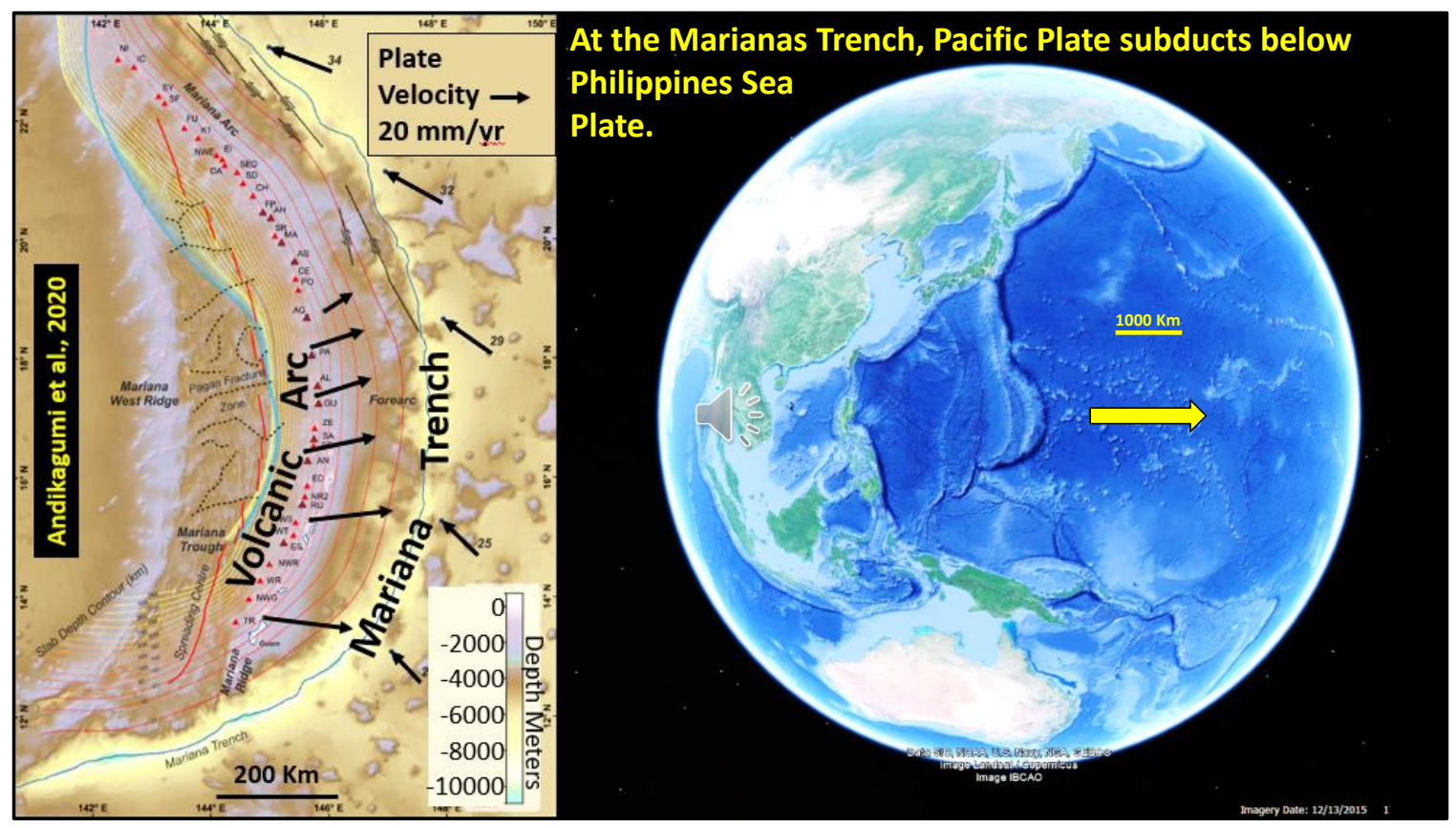

The Marianas Trench is moving from west to east as it rolls back through the Pacific oceanic plate. A question to ask is what might happen if a passive continental margin happened to lie over the horizon in the path of this migrating trench? 


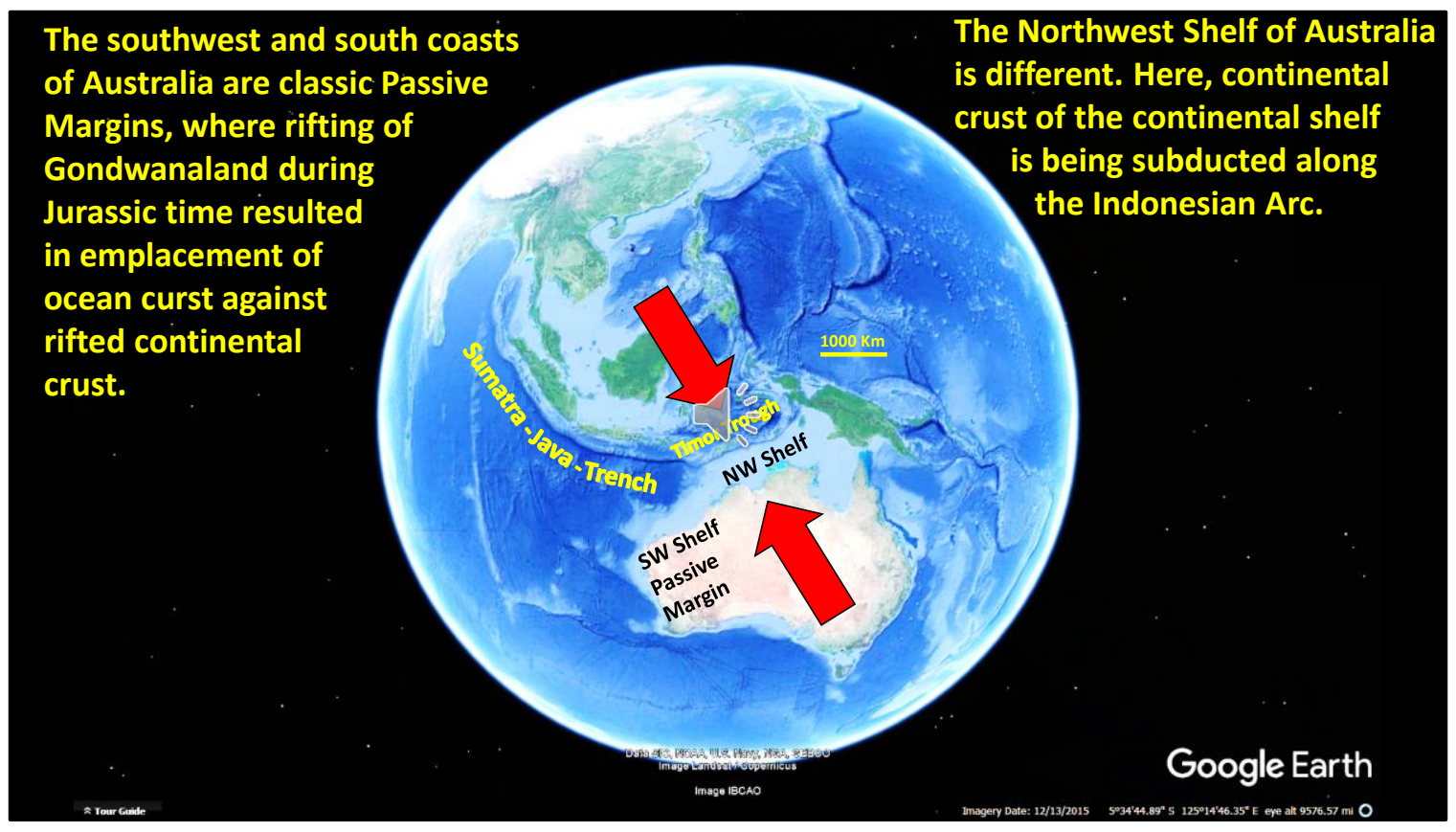

In the case of the Australian Plate, we don't have to imagine what might happen if a subduction zone encountered a passive margin. The northwest shelf of Australia has collided with the East Indonesia subduction zone. Australia rifted from Gondwanaland in Jurassic time and has migrated northward ever since. At the same time, the Indonesian subduction zone is moving south through the process of slab rollback. Simply by coincidence, these plates have encountered one another. This map shows that the south and southwestern coasts of Australia are still passive margins. It is only the Northwest Shelf that has encountered the Timor Trough in Recent time. 


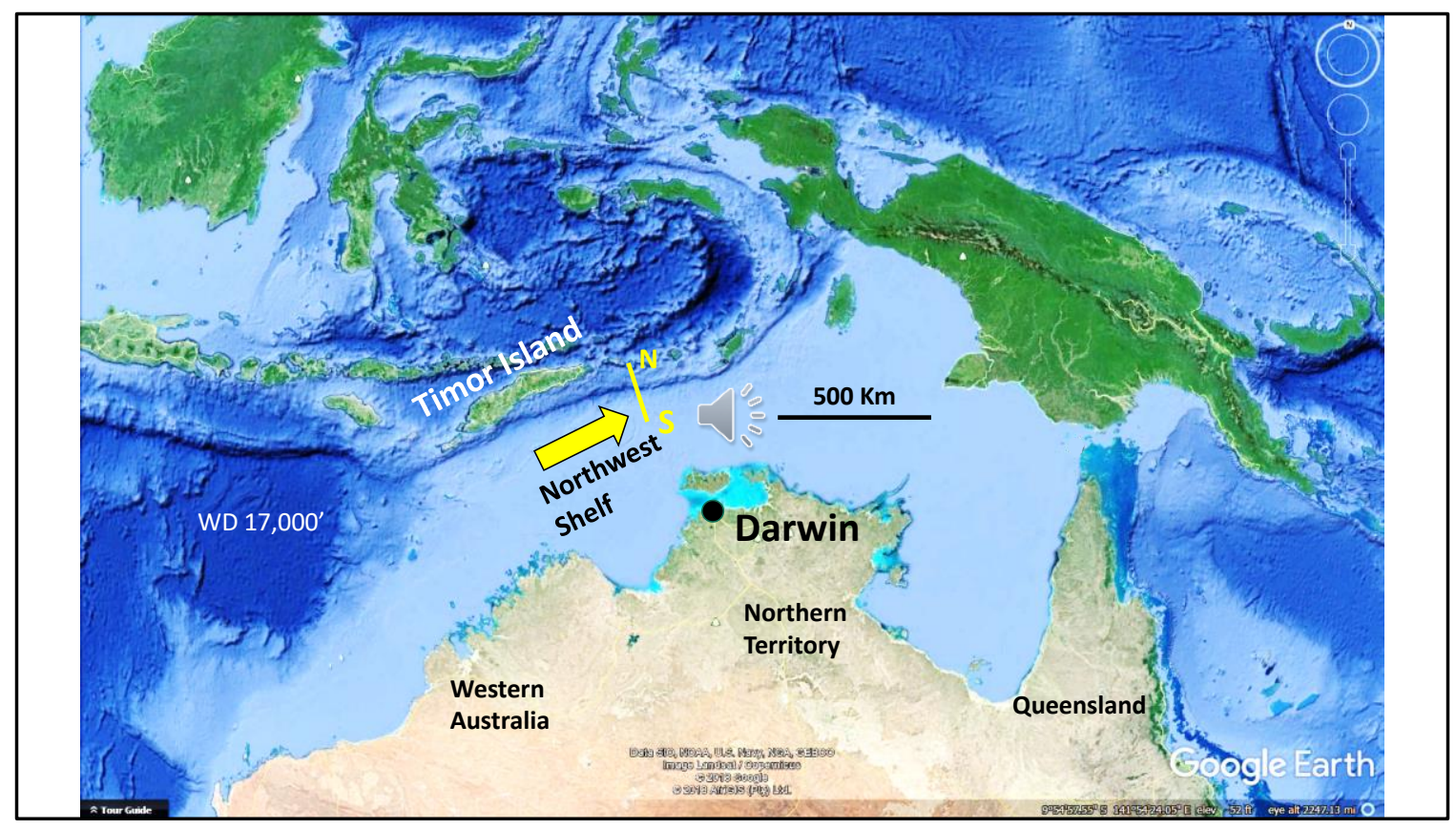

The yellow line shows the trace of a seismic line that extends from shallow water of the Northwest Shelf passive margin down into 10,000-foot water depths at the base of the Timor Trough. 


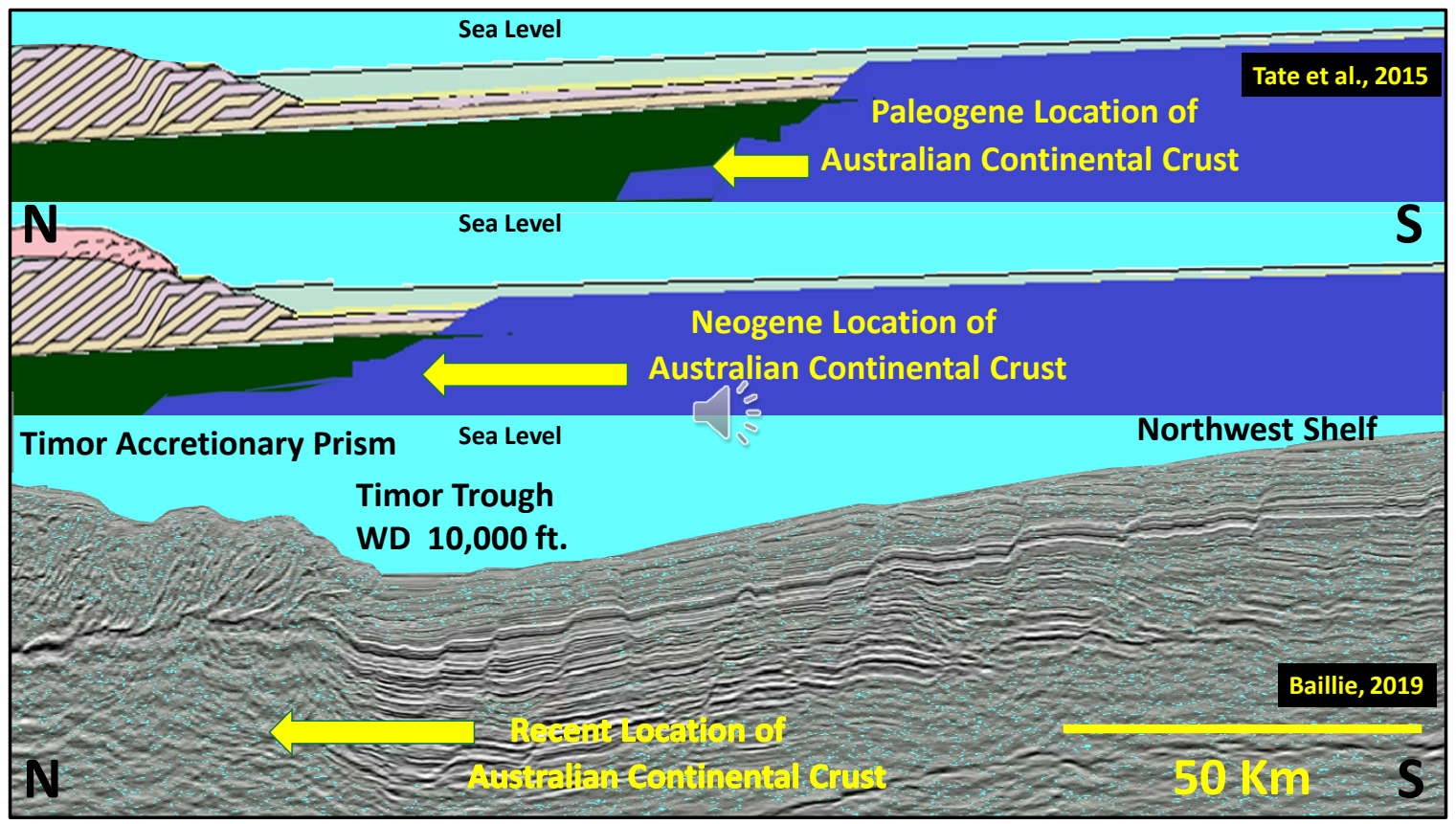

Continental Crust of the Australian Northwest Shelf is falling into the Timor Trough. Deepwater sediment scrapes off the descending plate and piles up into an accretionary prism. 

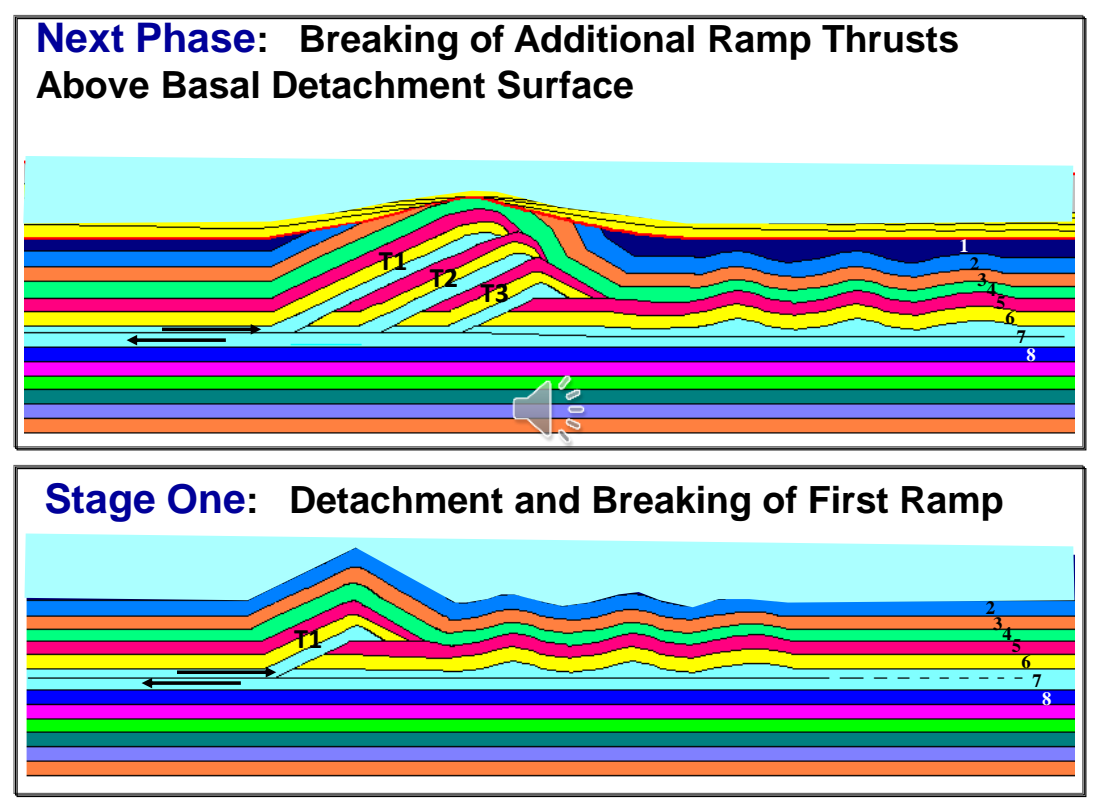

The accretionary prism is made up of a stack of imbricate thrust slices. The lower section shows formation of the first thrust above a basal detachment surface, at time 1. The upper section shows the formation of successively younger thrusts at times t2 and $t 3$. Note that the geometry at the youngest edge of the imbricates is always exactly the same, a simple fault-bend fold that rises up from the basal detachment at a low angle. However, as younger thrusts form, they lift up the older thrusts behind them. The youngest thrusts occur at the bottom of the subduction trench, while older thrusts are lifted successively higher in the accretionary prism. This is relevant to the the structural geology of the upper plate of the Roberts Mountains Thrust. 


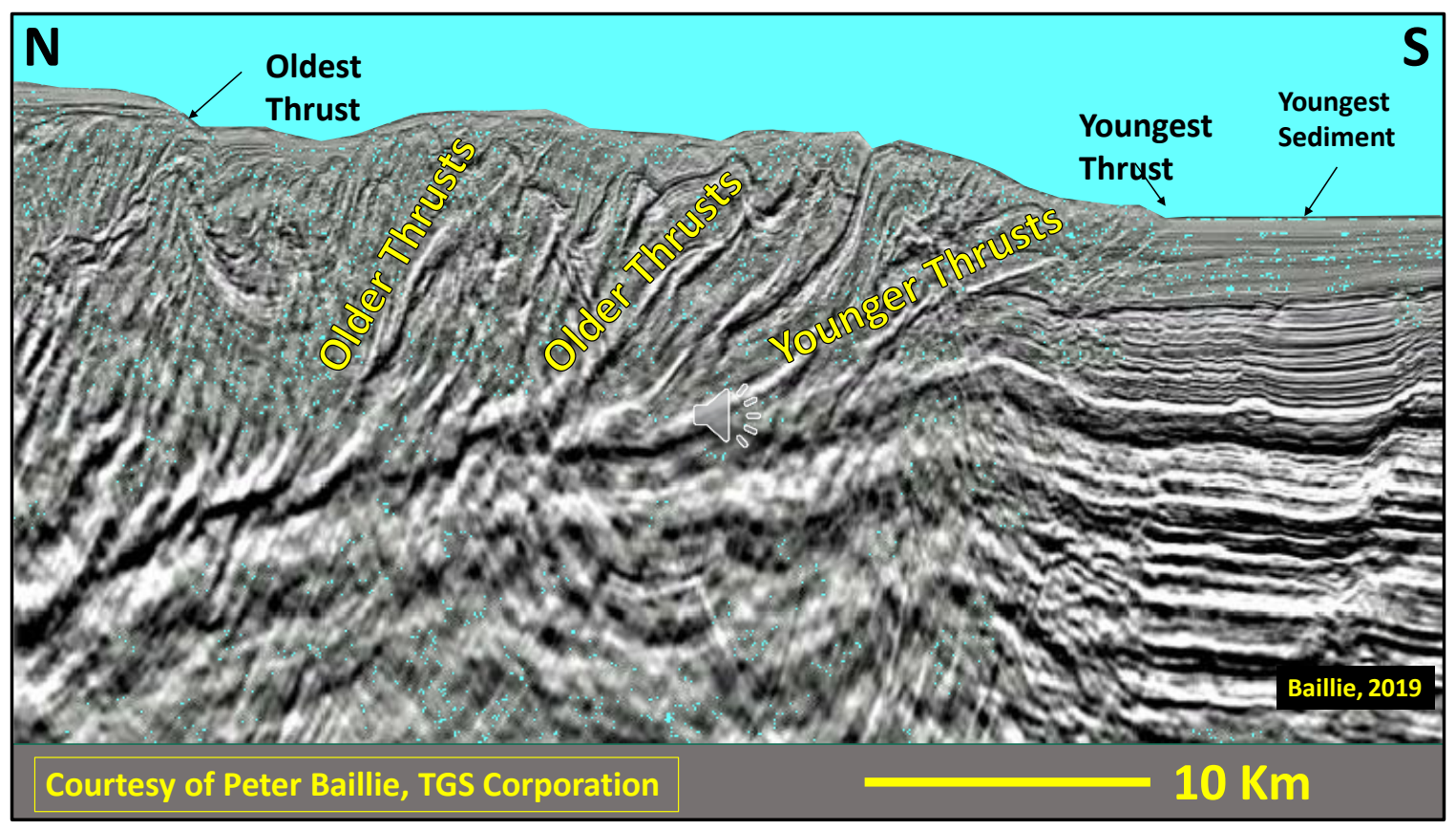

This detail of the Timor Accretionary Prism shows a classic sequence of forwardbreaking thrusts. The oldest sediment is stacked into the highest part of the prism, while the youngest sediment is cut by the youngest thrust right at the bottom of the trench. 


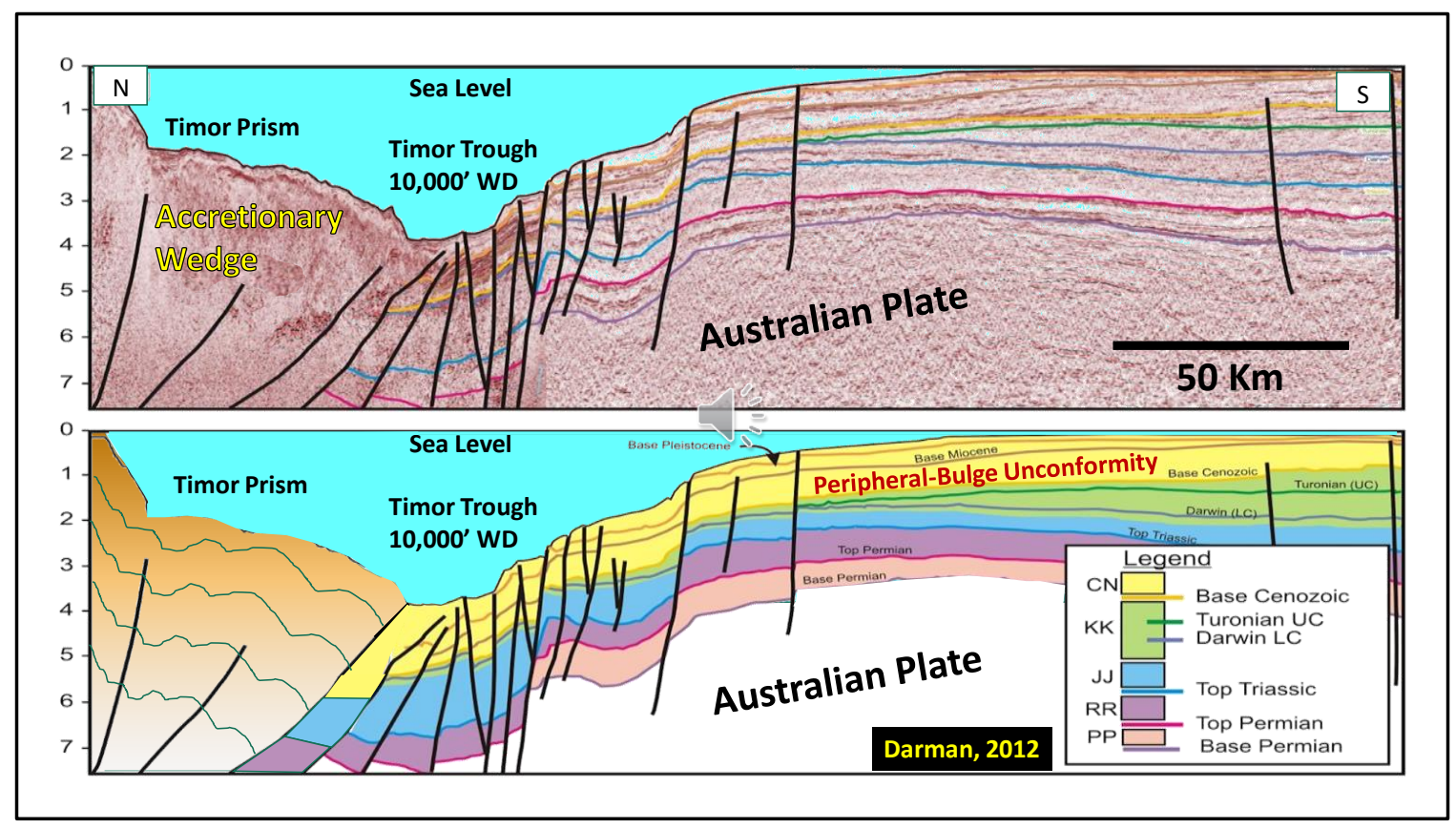

This line across the Timor Trough stretches for more than 300 kilometers, from water depths of a few tens of feet on the shelf, to more than 10,000 feet deep at the bottom of the trough. Note that as Australian plate descends, it bends toward the trench, and this flexing results in tension and normal faulting. Farther inward to the south, the flexing of the plate results in uplift of a broad Peripheral Bulge and consequent development of tectonic unconformities between successively younger sedimentary sequences. This line captures the essential characteristics of a passive margin as it encounters a subduction zone. Shallow water carbonate sediments descend into deeper water and become overlain by deep-water mudstones; the mudstones scrape off and pile up on top of the shallow water carbonates. 


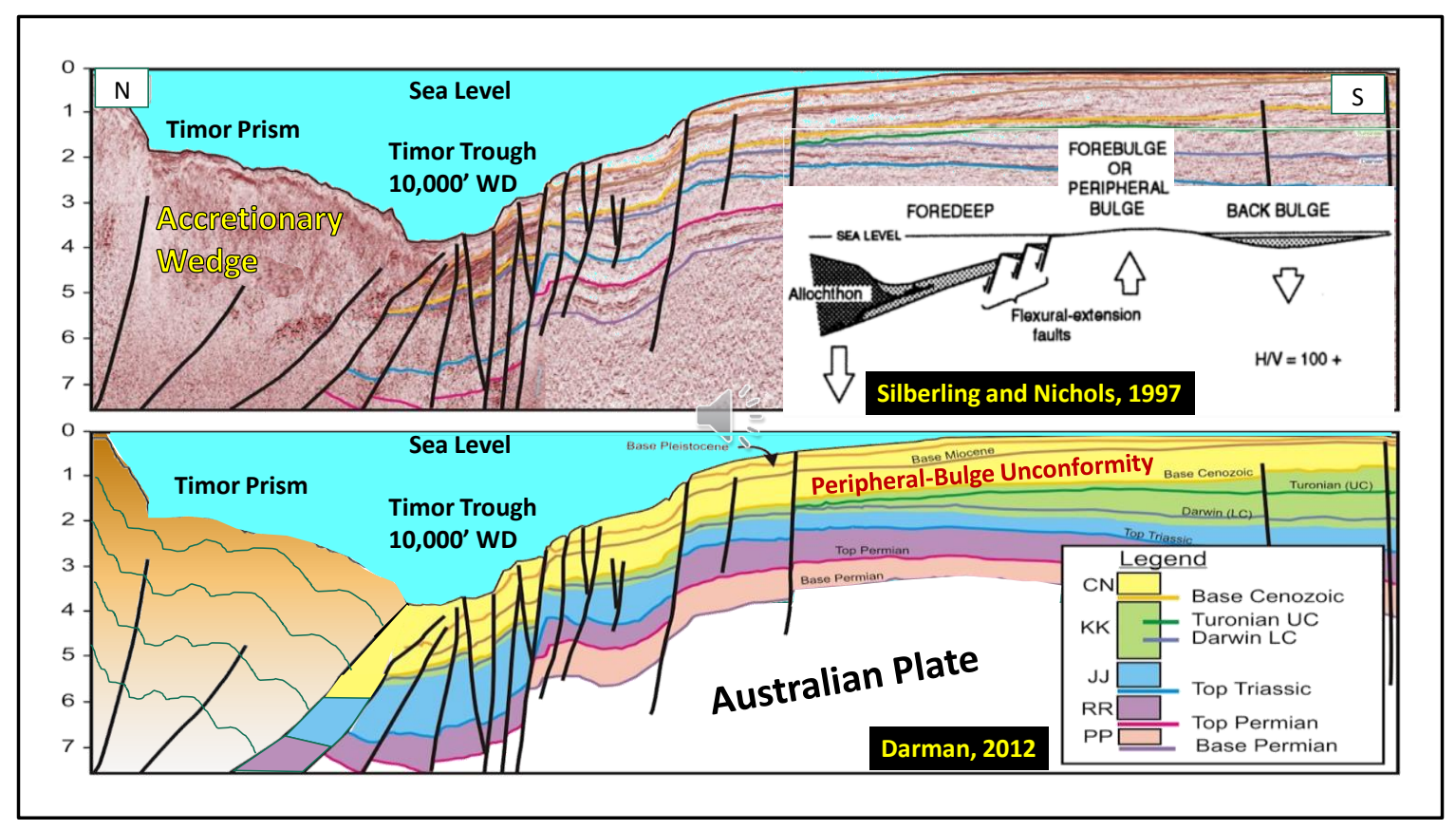

The insert on the right center shows a conceptual structure section through central Nevada at the time of the Antler Orogeny. You can see by the dates on both sections that there is no way that Silberling and Nichols could have seen this seismic line, but their geologic concept seems well represented by real data from the Northwest Shelf. The analogy suggests that there is merit to this concept. 


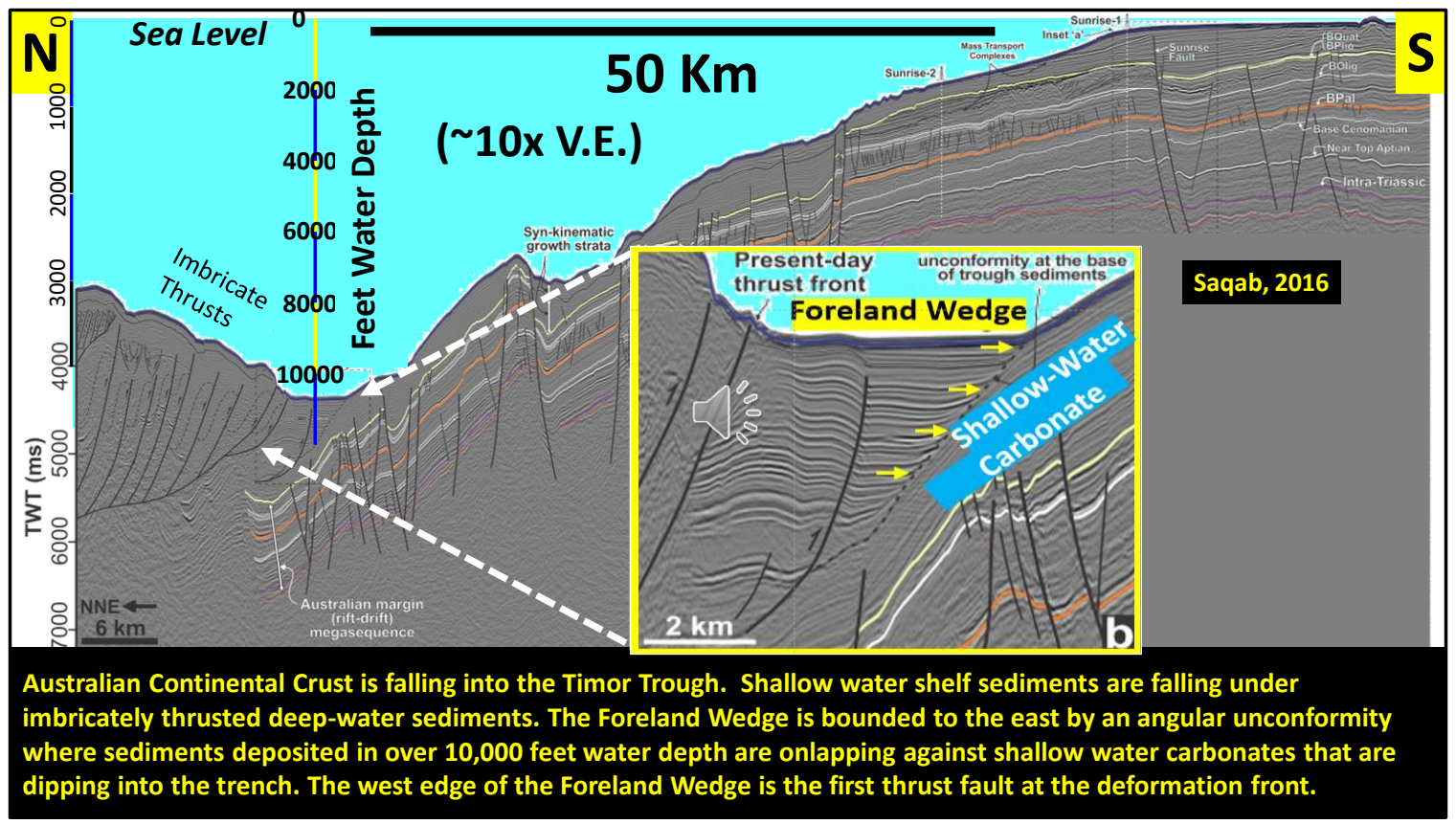

The Australian carbonate platform is falling into the Timor Trough. Shallow water shelf sediments are falling under imbricately thrusted deep-water sediments. The plate descends from sea level to over 10,000 feet water depth over a distance of less than $100 \mathrm{~km}$. Note all the normal faults in the descending plate that formed due to flexing of the plate as it falls into the trench. The Foreland Wedge is sediment deposited in the bottom of the trench. 


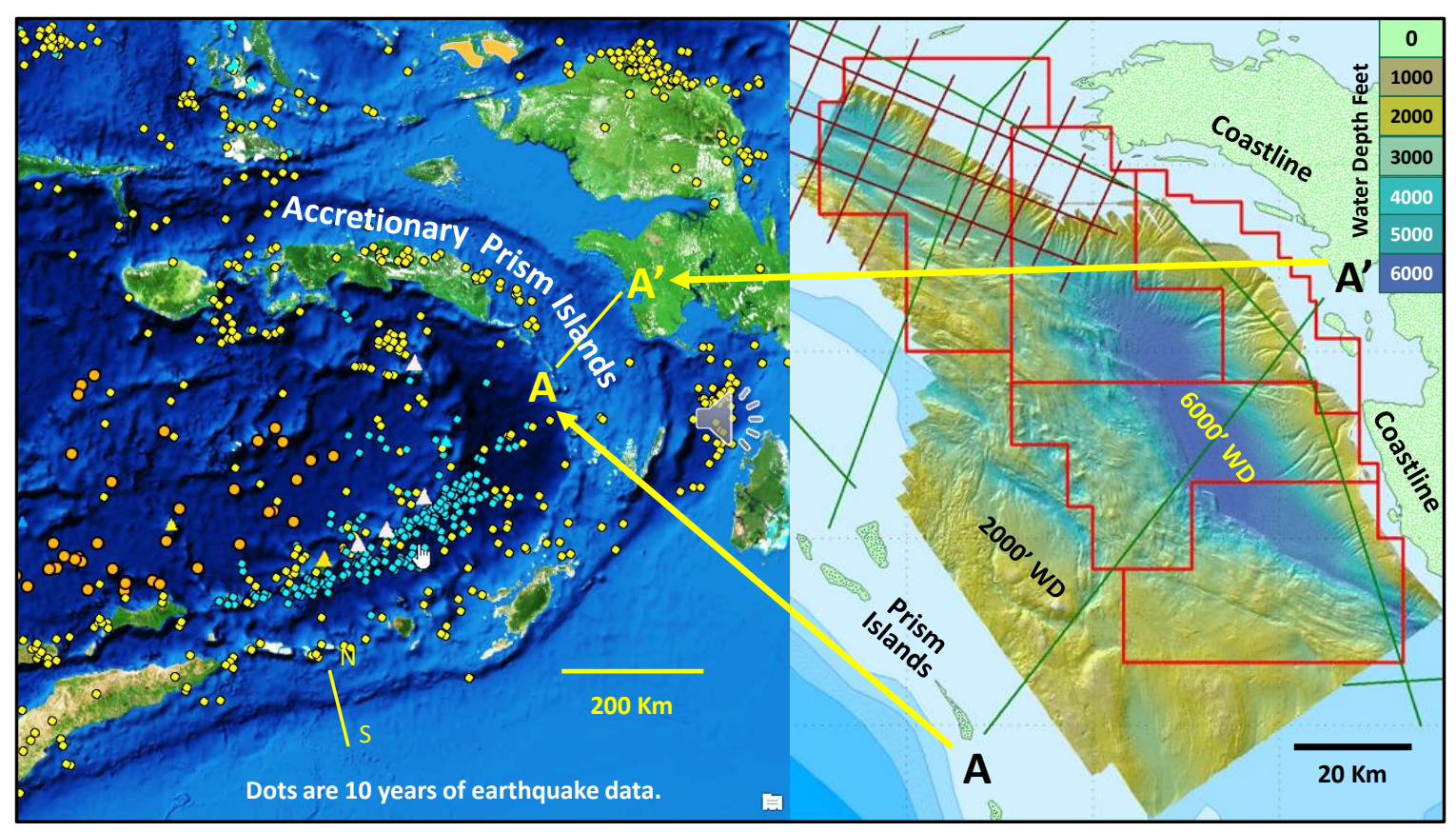

This map shows the location of a seismic section at the western tip of New Guinea. The water depth along the line ranges from sea level on the New Guinea coast at $A^{\prime}$ to over 6000 feet at the bottom of the Banda trough, and then back up to sea level at location $A$, where the accretionary prism rises above sea-level to form a chain of nonvolcanic islands of uplifted deep-water sediment. 


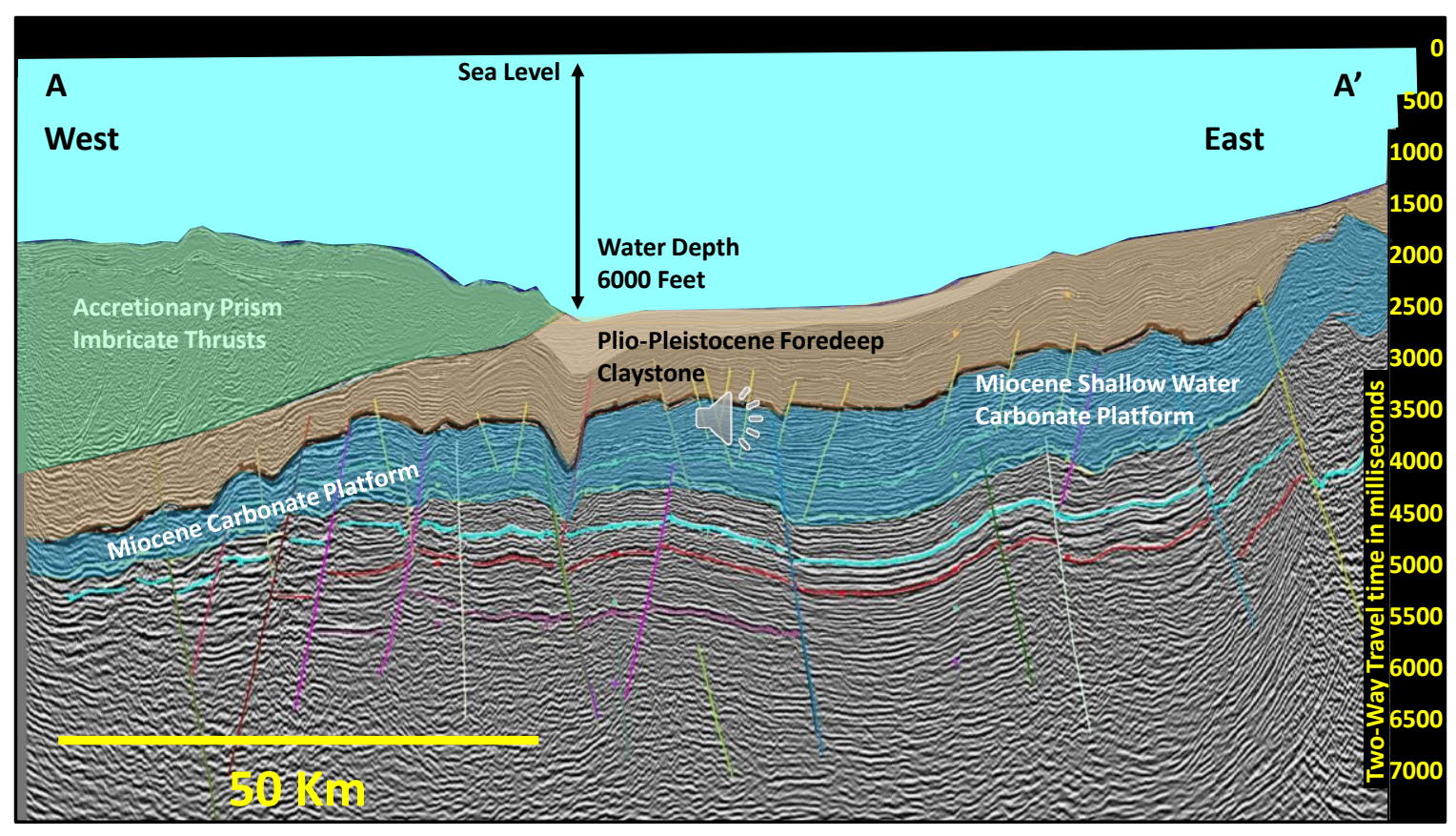

Data from exploration wells establish that a Miocene shallow water carbonate platform is falling into the Banda Arc subduction zone. A detachment surface separates the subducting lower plate from an overlying accretionary prism of sediment that was scraped off the top of the descending plate. The Miocene carbonates were deposited in shallow water, but as subsidence accelerated in Pliocene time due to descent into the trench, the carbonate platform stopped growing due to drowning, and became overlain by deep-water Plio-Pleistocene mudstones. 


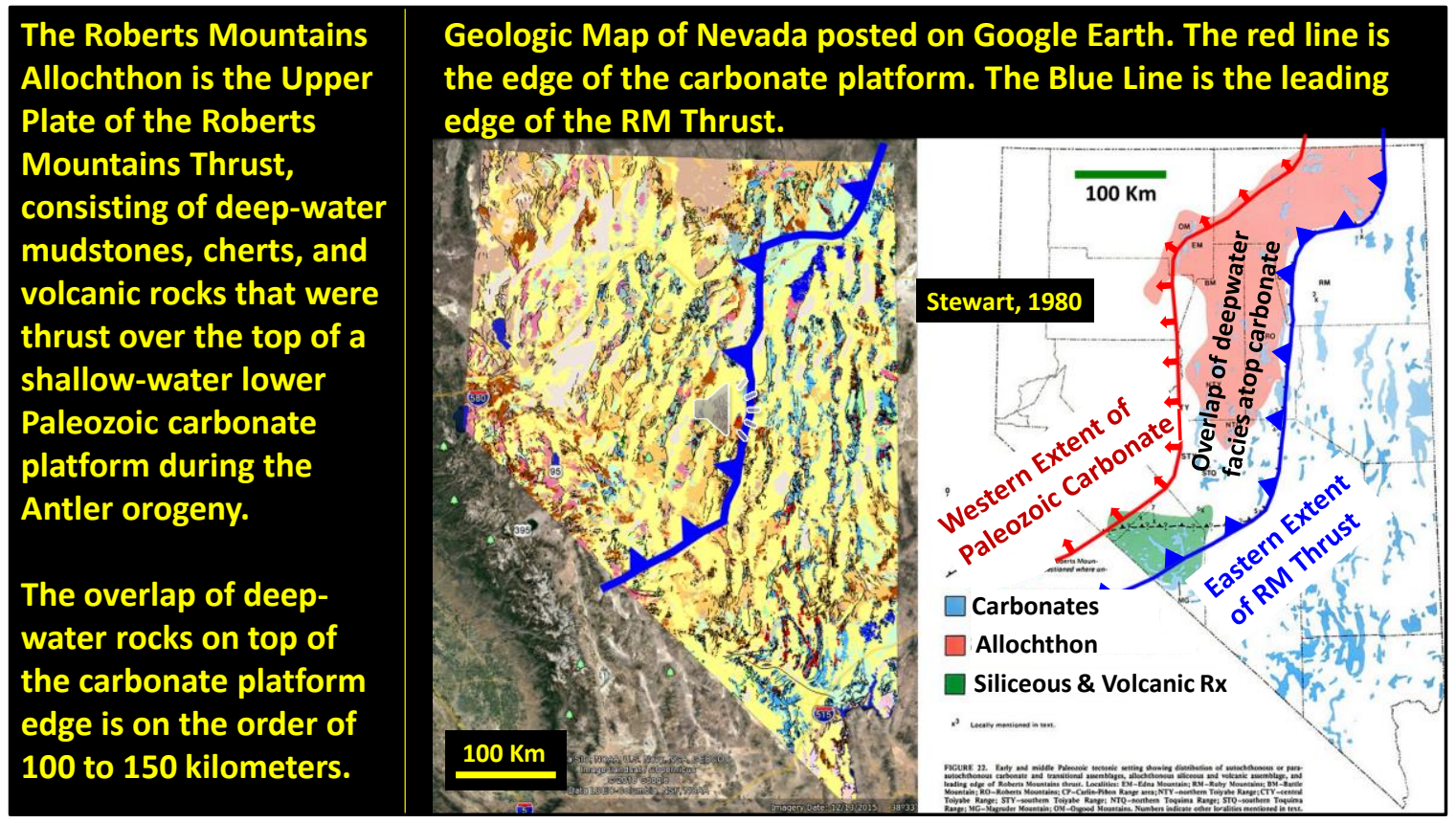

This overlap between the east edge of the accretionary prism and the west edge of the carbonate platform is a feature seen along the trace of the Roberts Mountains thrust all across Nevada. The Blue line is the leading edge of the thrust, while the red line is the farthest westward extent of Devonian shallow water carbonate rocks. The amount of overlap is on the order of 100 kilometers. 


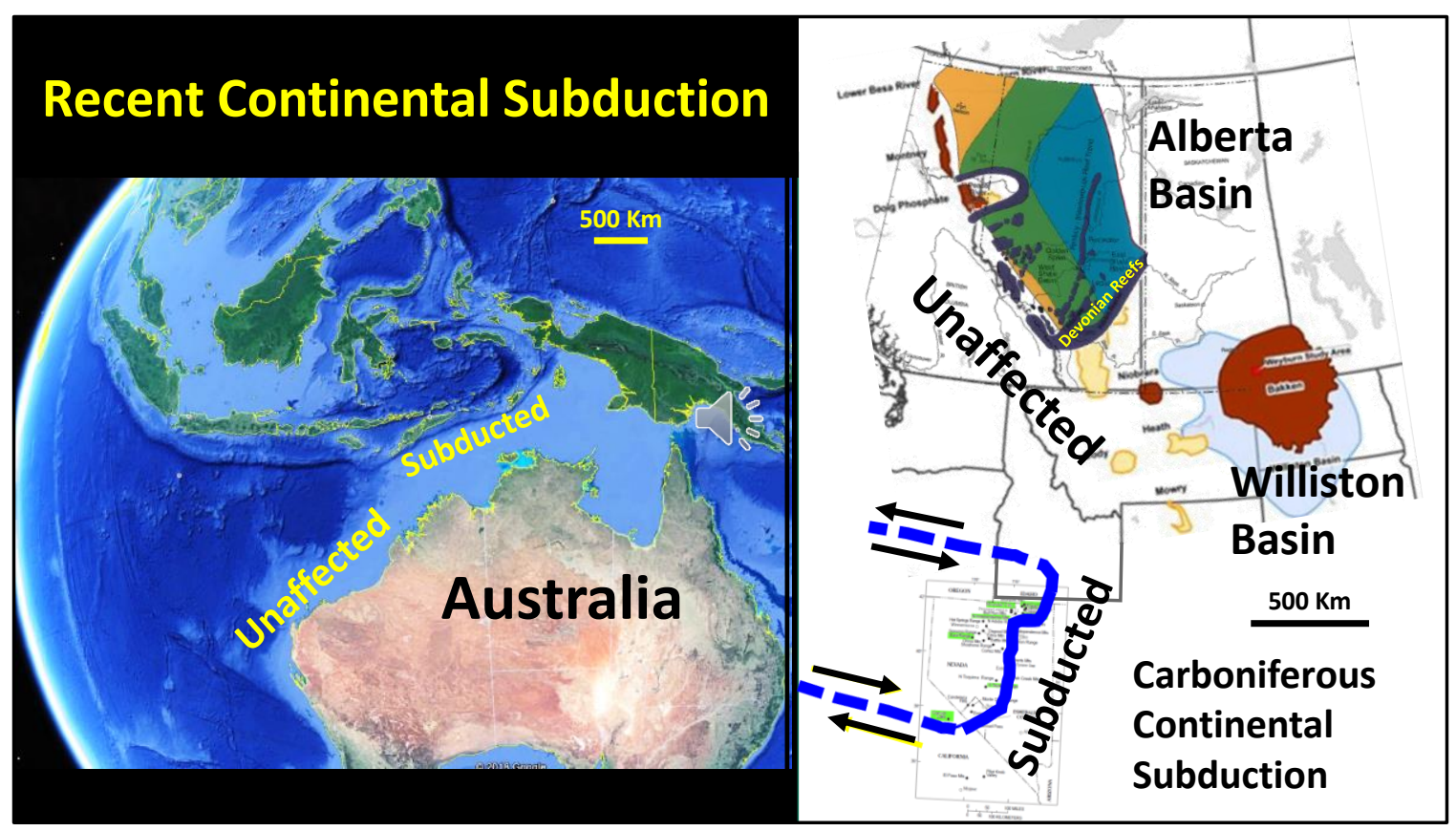

We've seen that continental subduction does take place where a passive margin encounters a subduction zone. But subduction zones do not go on forever. They may terminate at transform faults, or they may curve away from the edge of a passive margin. In the case of Australia on the left, the Indonesian subduction zone curves to the west and leaves the southwest shelf completely unaffected. The map on the right shows that the Alberta and Williston Basins show continuous sedimentation from the Devonian up through the Carboniferous and Permian. These areas were not affected by the Antler Orogeny. The Roberts Mountains trench may have terminated at Transform Faults to the southwest of those basins. 


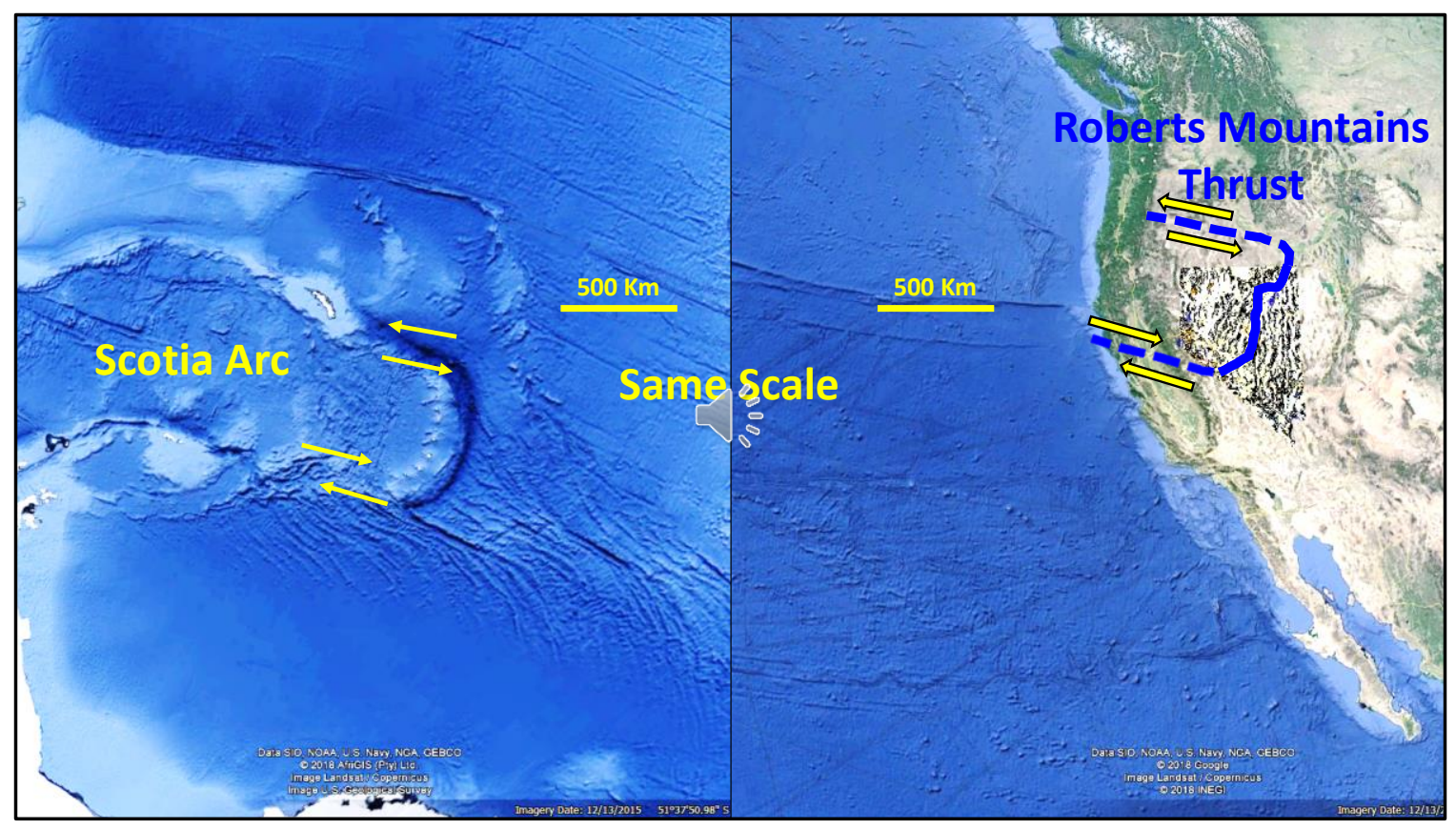

This brings us back to a comparison of the scale of the Roberts Mountains Thrust and the Scotia Arc subduction zone at the same scale. It is a fact that the Roberts Mountains thrust dies out to the north and south since there are Paleozoic sections in both directions that show continuous sedimentation from the Devonian into the Carboniferous without the deformation seen in Nevada. Though their precise location isn't known, there must be transforms at either end of the Roberts Thrust. 
The Roberts Mountains

Allocthon consists of pelagic claystones and radiolarian cherts that are emplaced atop of the Paleozoic Carbonate Platform of Laurentia, the ancestral continent of Western North America. The allochthon was recognized as an exotic terrain by Merriam and Anderson in 1942. The most detailed and famous section of the allochthon was excavated by Stan Finney. This section is still referenced in recent publications.

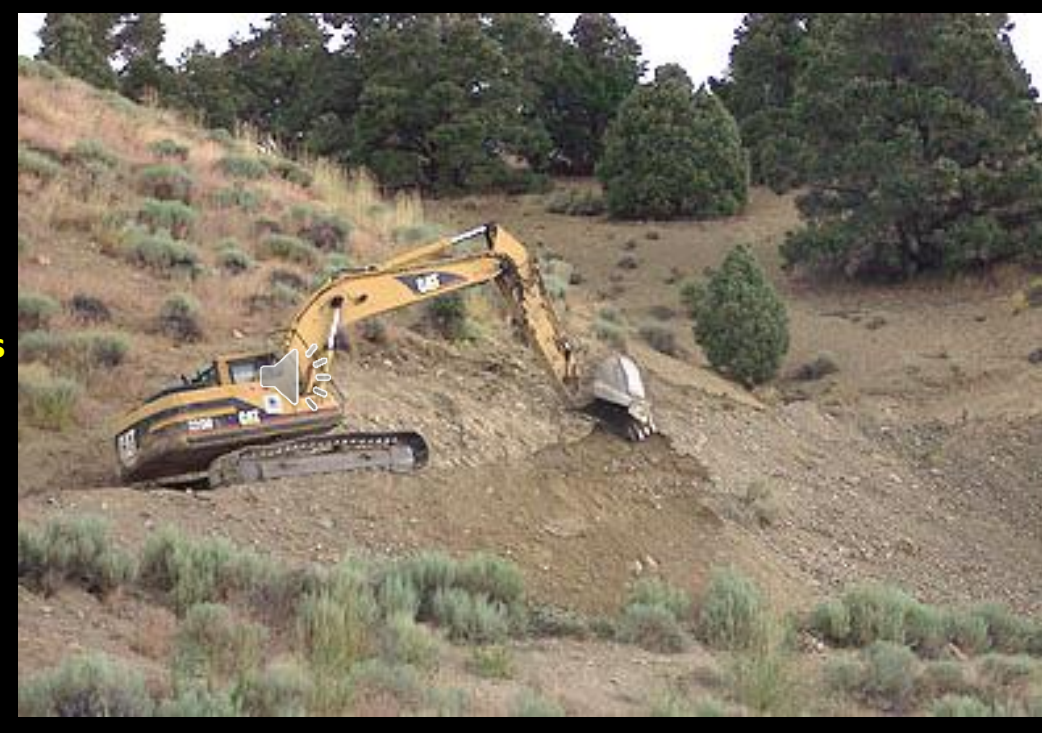

Photo by Stan Finney from Vinini Creek in the Roberts Mountains

Professor Stan Finney has carried out detailed analyses of the upper plate of the Roberts Mountains Thrust. Professor Finney cut trenches to get the best possible exposures of the pelagic claystones and radiolarian cherts in the Roberts Mountains allochthon. 


\section{Timor Accretionary Prism}

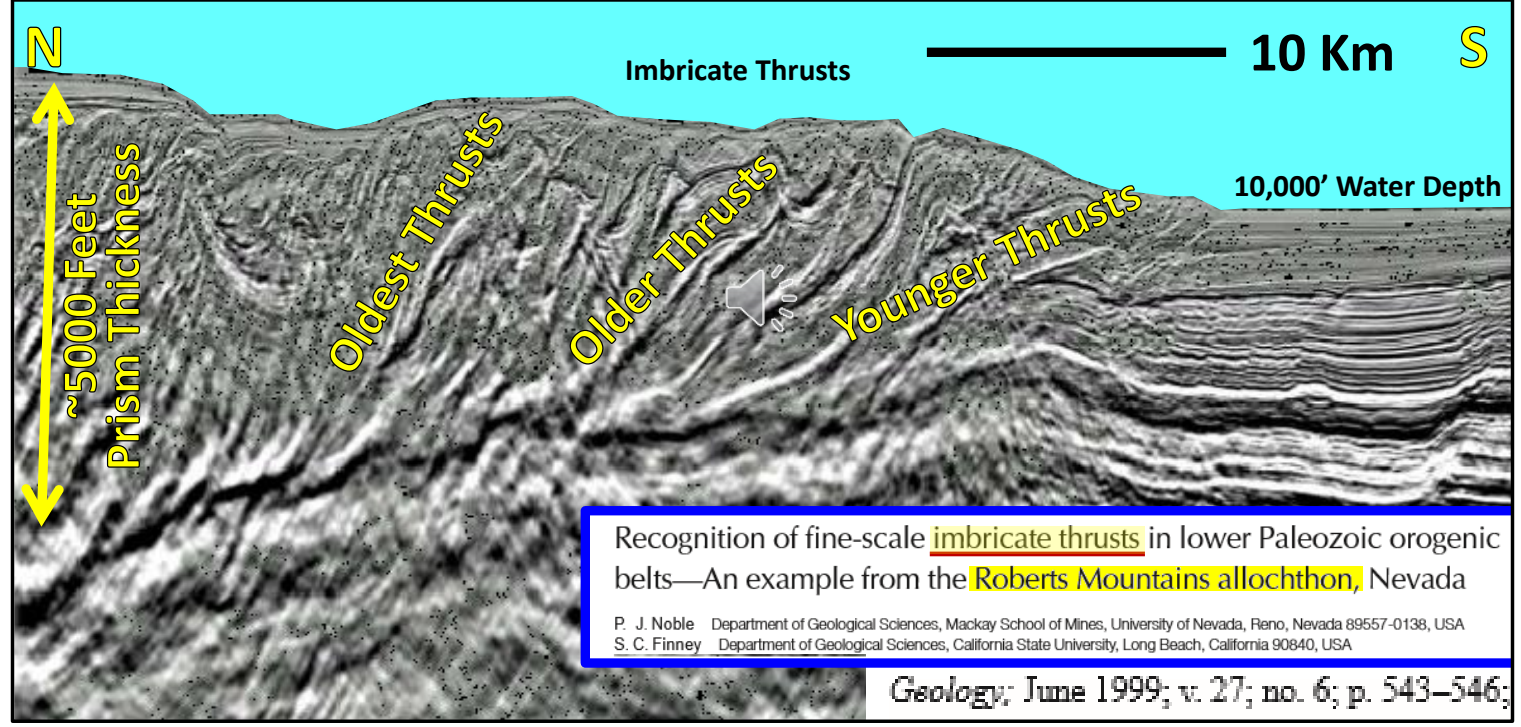

Biostratigraphic data led Finney to the conclusion that the upper plate was not a single sheet, but rather a collection of imbricate thrusts. This is what one would expect in an accretionary prism. 
Sheets, Mitchell, Melchin, Loxton, Storch, Carluci, and Hawkins, 2016: Graptolite community responses to global climate change and the Late Ordovician mass extinction: PNAS v. 113 (30) p.83808385:

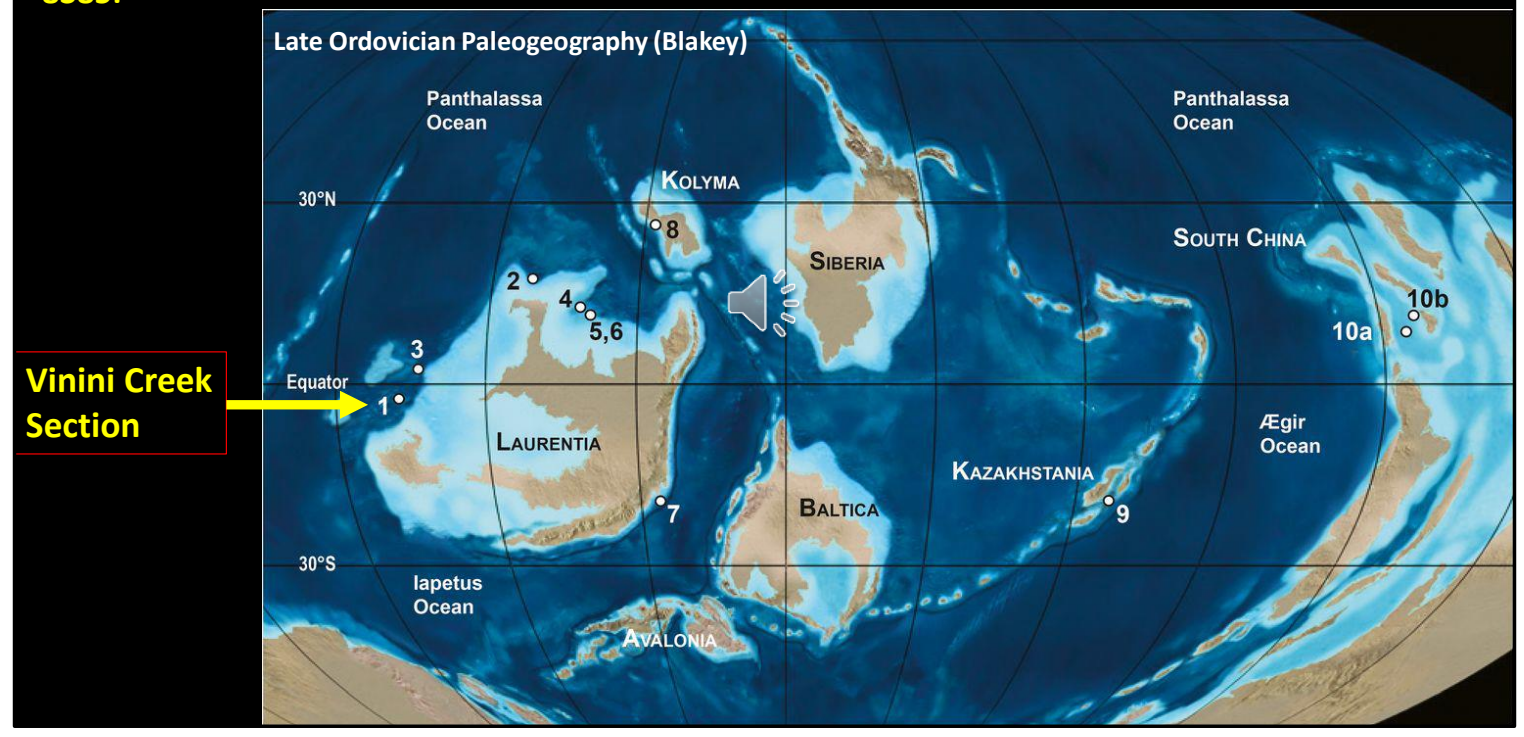

Furthermore, Finney's work led to recognition that many of the fossils encountered in the pelagic mudstones were similar to those found in the lower plate of the Laurentian carbonate platform. Paleogeographic reconstructions interpret that these fossils must have been transported into deep water from an adjacent Laurentian continental shelf. Since the upper plate contains fossils from Laurentia, how could it be possible that the Roberts Mountains Allochthon is an exotic terrain that crashed into the Laurentian shelf? 


\section{Subduction Zone to West}

\section{Passive Margin to East}

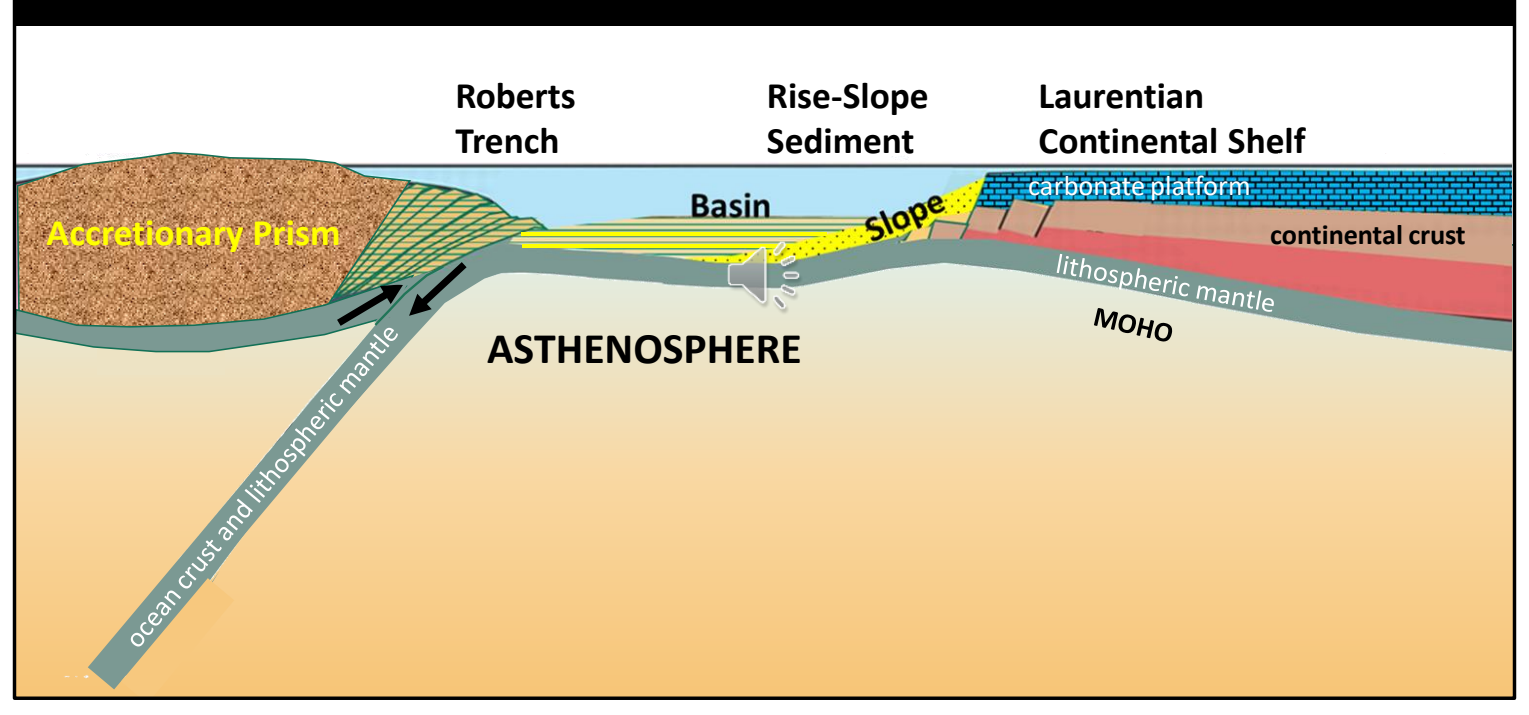

This diagram attempts to explain how the accretionary prism could contain fossils from the Laurentian shelf. I worked on similar deep-water sediments in Indonesia, where we found mangrove leaves scattered within turbidity current deposits.

Mangroves only grow within the intertidal zone along coastlines, yet they may be transported for hundreds of kilometers offshore into deep water. Basinward from the edge of the Laurentian continental shelf, there would be a Continental Slope that would consist entirely of sediment transported from the adjacent shallow shelf. Basinward of the continental slope would be a continental rise consisting of a mix of deep-water pelagic sediment including clay and Radiolaria, and thin turbidite layers containing material from the shelf and slope. 
Laurentian shelf slides under deepwater sediments due to subduction driven by gravity. The rise and slope sediments contain fossils transported from the adjacent shallow water carbonate platform by turbidity currents.

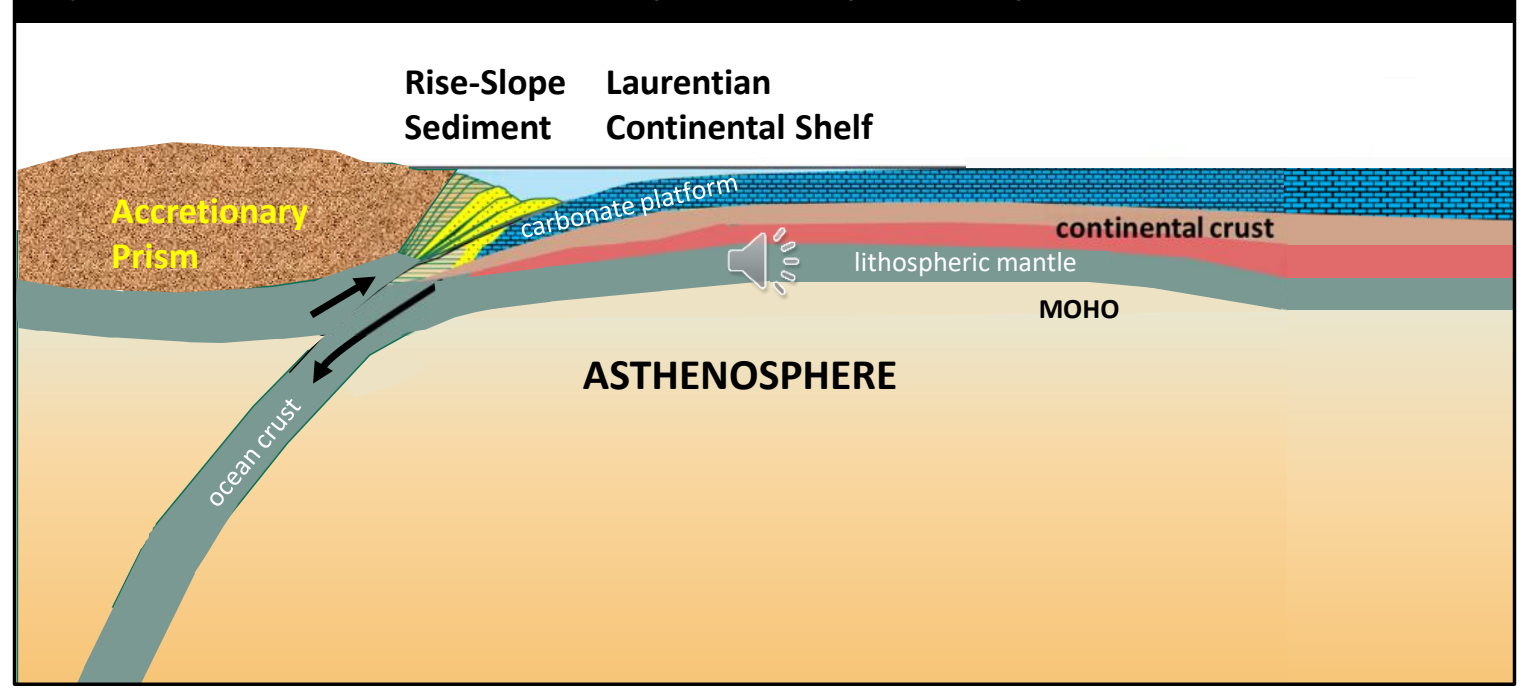

As the passive margin approaches the trench, material from the Laurentian rise and slope is scraped up into the accretionary prism. The accretionary prism now contains fossils that were transported from the adjacent Laurentian shelf. Eventually, the shallow water carbonate platform begins its descent into the trench, and slides below the accretionary prism in Latest Devonian to Mississippian time. By this time, a stack of imbricately thrusted deep-water sediment containing fossils from shallow water, has been emplaced atop shallow-water carbonate platform sediments. 
Deepwater rise and slope sediments containing fossils from the shelf are now emplaced atop the shallow water carbonate platform. Basalt slab descends into mantle. Accretionary prism rebounds and sheds rock-fragment "molasse".

\section{Permian Landmass}

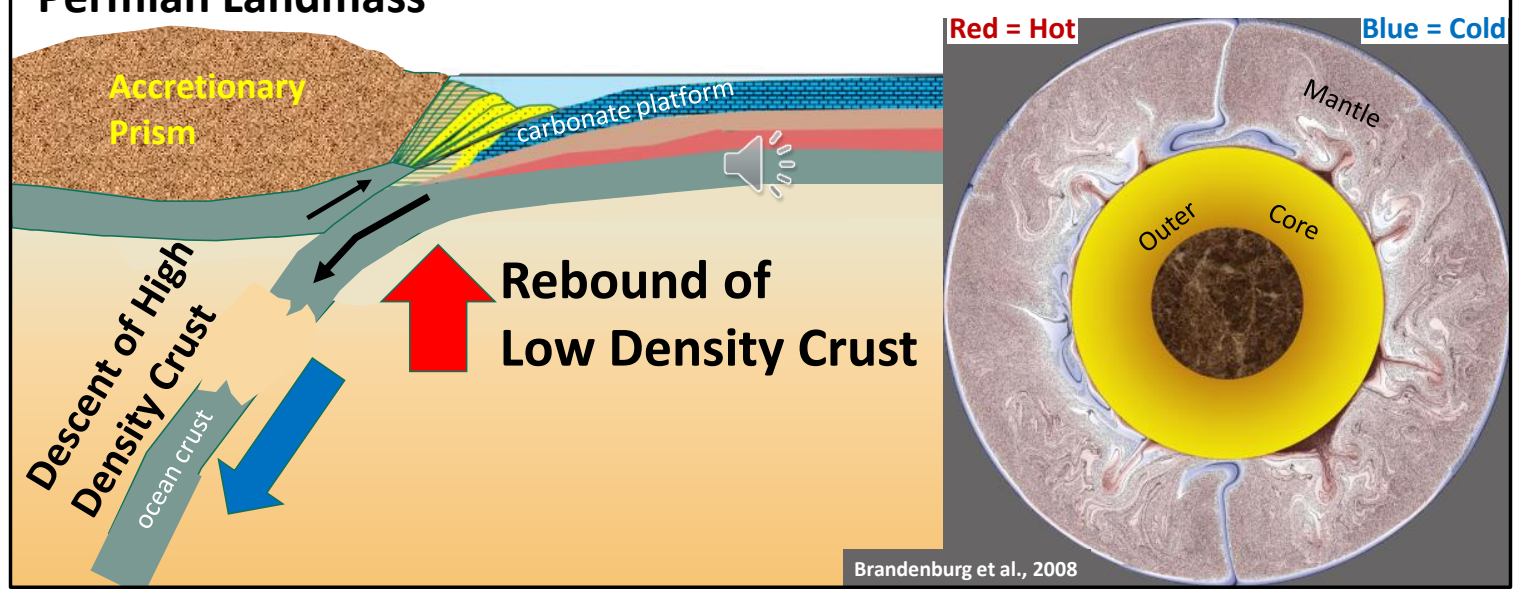

The relatively low density of continental crust means that it will not continue to subduct into the mantle. Eventually it sticks, and the basalt part of the plate will break off and the continental part will rebound to some degree, accentuating the uplift of the Accretionary prism. In the case of Timor Island in Indonesia, the exposed landmass reaches 1000 meters elevation. The figure on the right is a computer model based on seismic tomography that shows cold dense subducted lithosphere descending to the base of the mantle. 


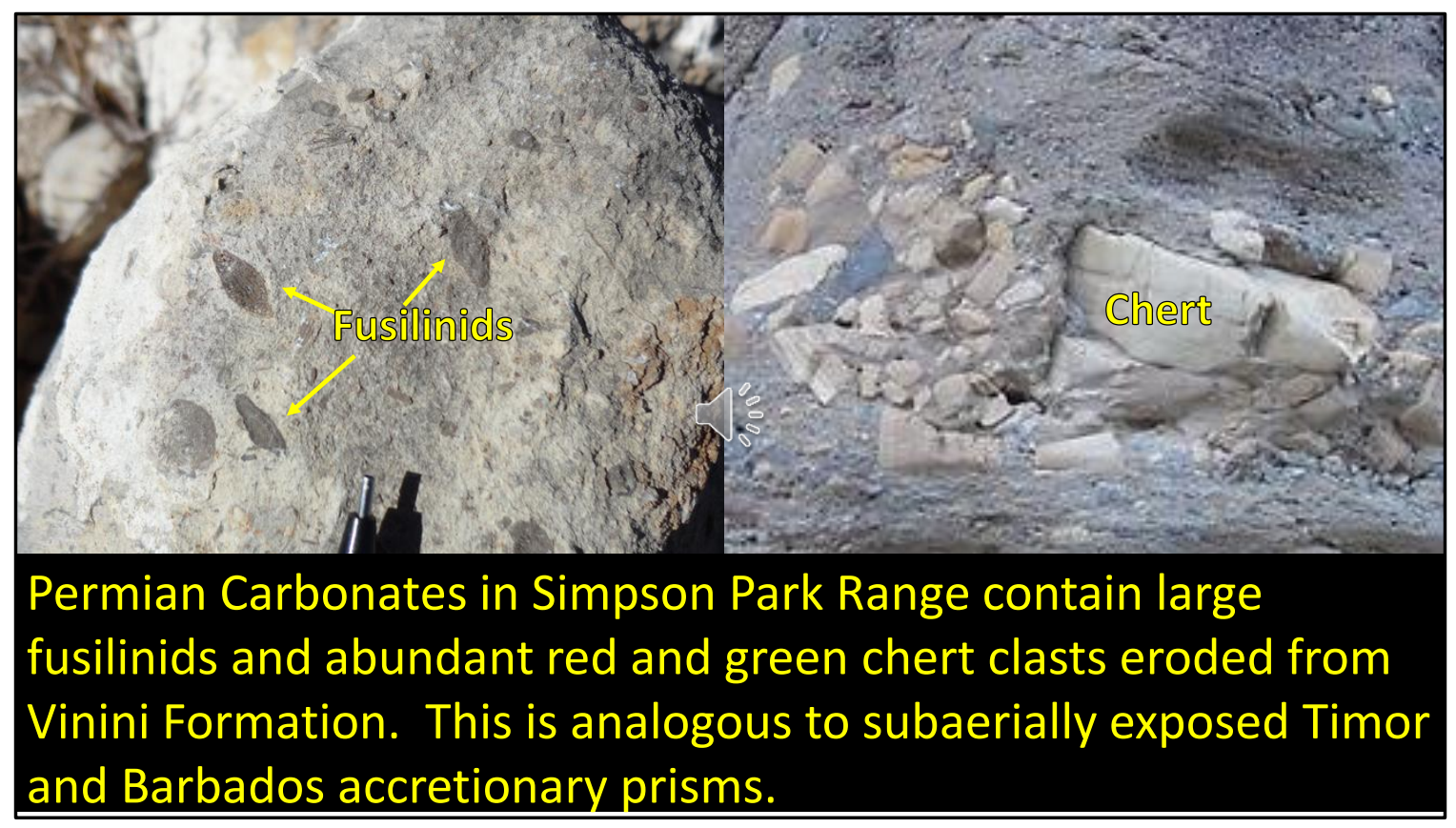

Analogous to Timor Island, traces of an uplifted Permian landmass in Nevada are seen in "mollase" deposits containing eroded deep-water radiolarian chert clasts and shallow water Permian fusilinid limestones. 


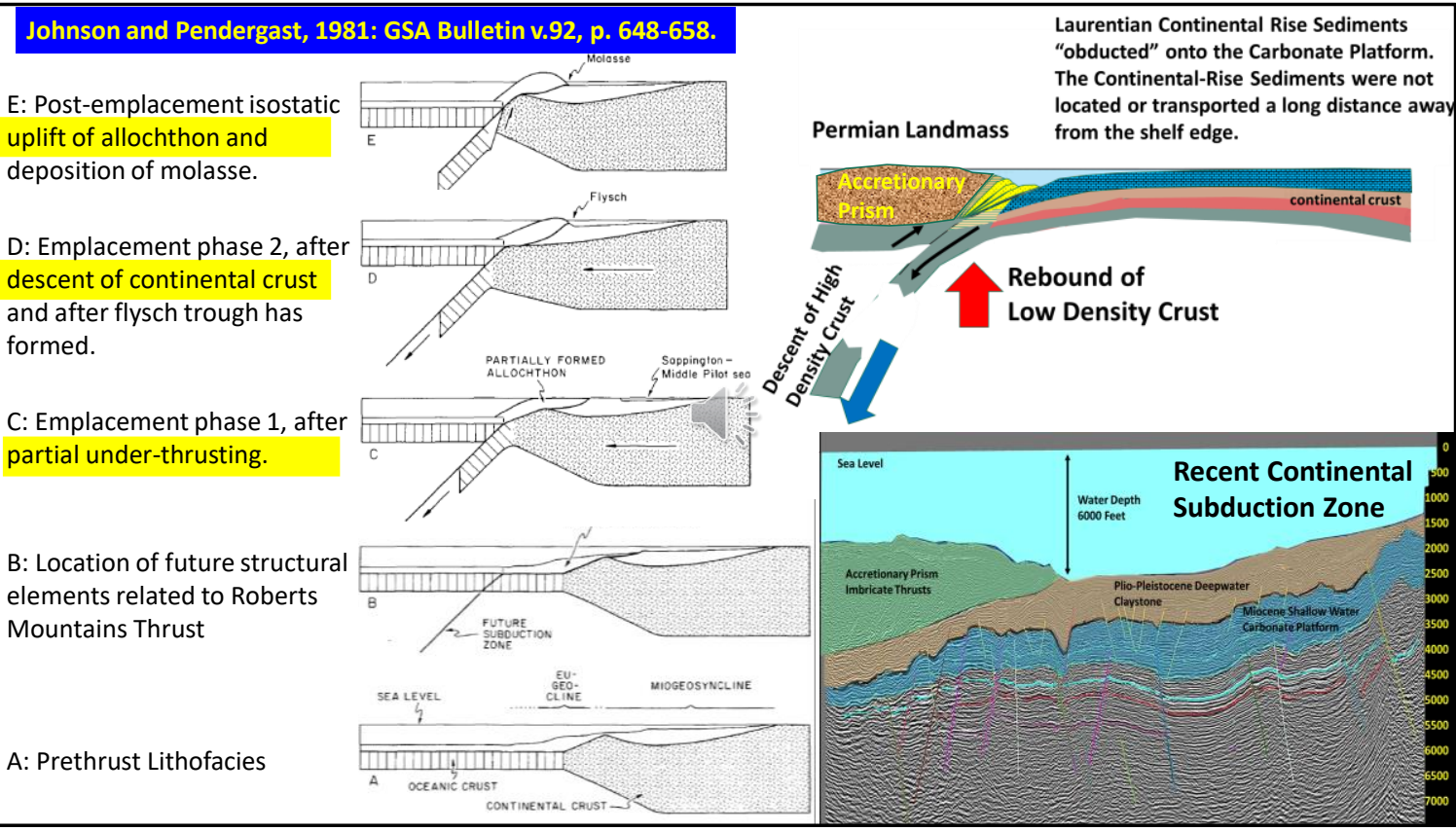

This is Jess Johnson's interpretation from 1981. It is similar to what I've shown, just a little harder to see. He has the "Eugeosynclinal" slope and rise sediments emplaced on top of the "Miogeosyncline" by means of descent of continental crust. "Mollase" is derived from the uplifted allochthon. Analogs make it easier to visualize this, using examples from Recent continental subduction zones. This is why geologists go on field trips; to see new things and get new ideas. I'm sure that Jess would have liked to visit Timor Island. 


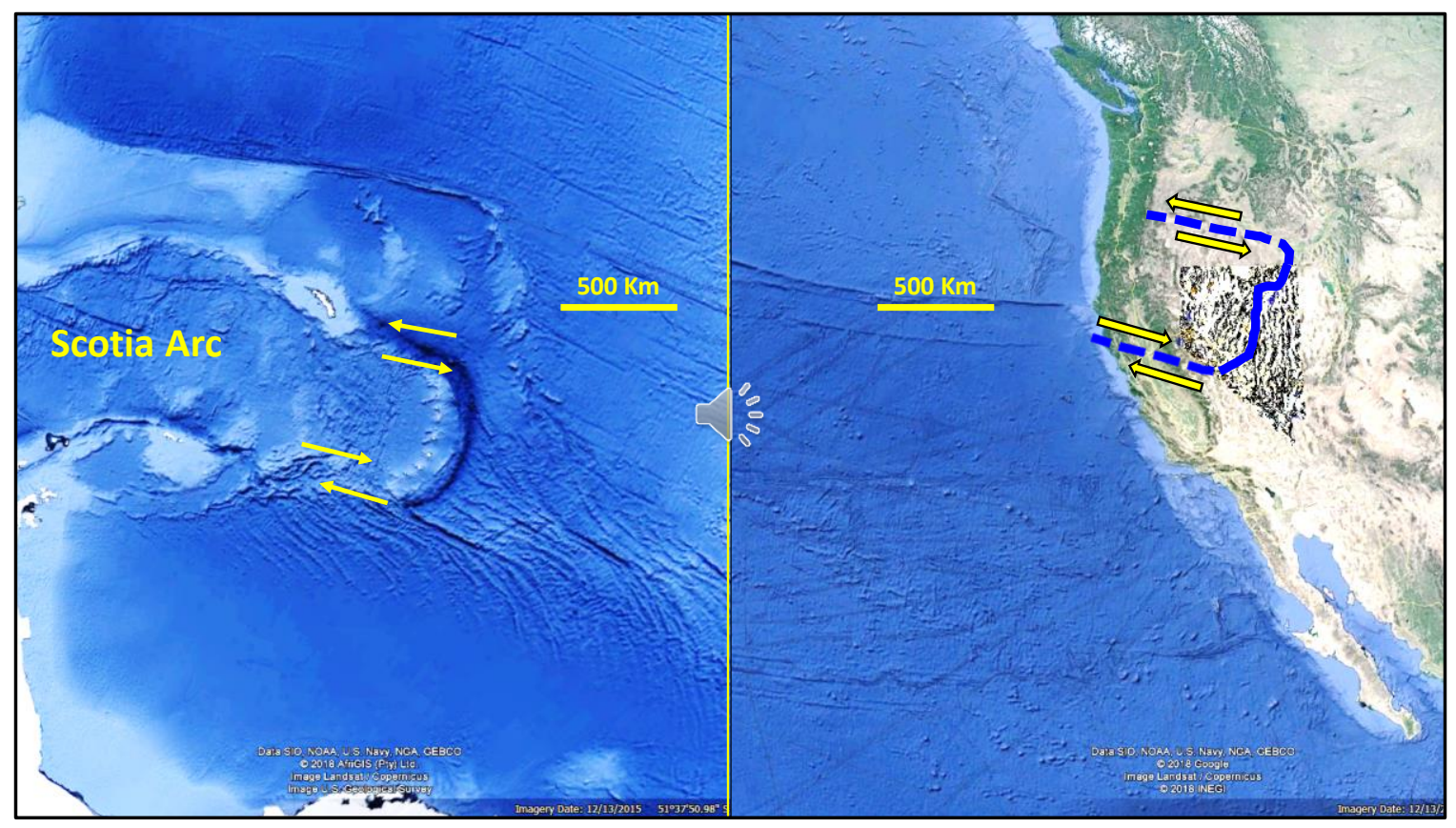

But if an island arc collided with the Laurentian shelf, then where are the volcanic rocks? 
Deep-sea origin of Ordovician pillow basalt and associated sedimentary rocks, northern Nevada: CHESTER T.

WRUCKE, MICHAEL CHURKIN, CHRIS HEROPOULOS J, US. Geological Survey: GSA Bulletin, v. 89, p. 1272-1280

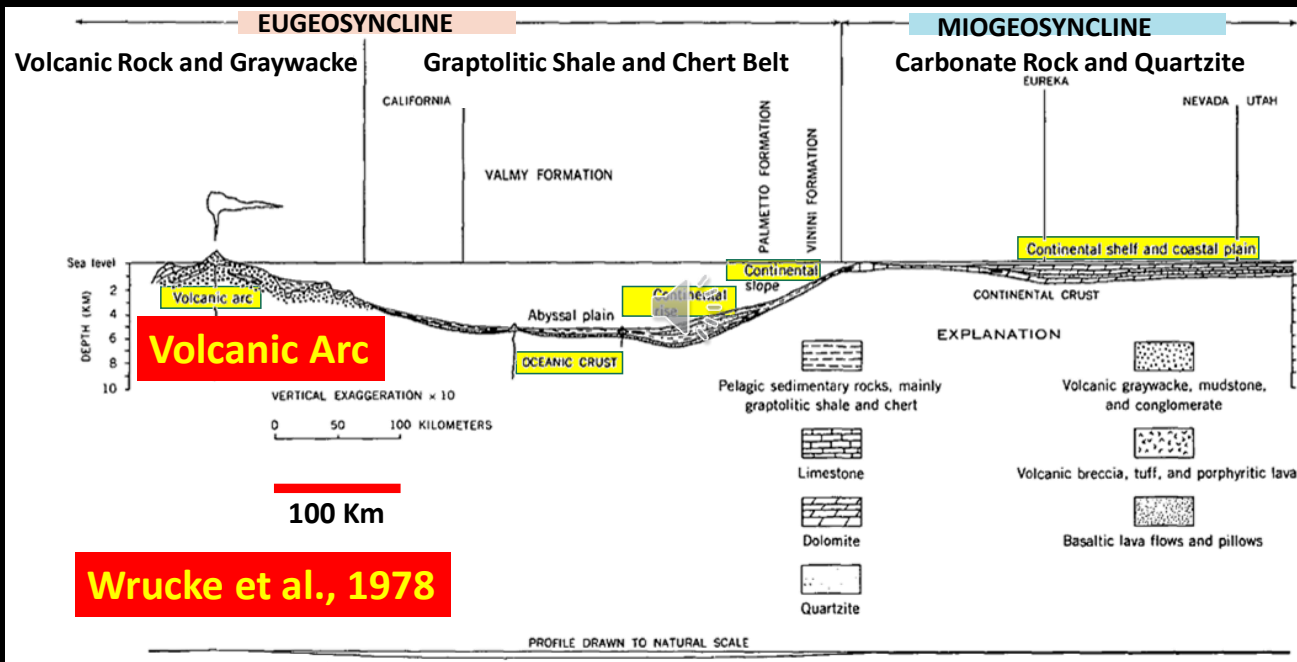

Figure 6. Cross section of western margin of North America in Late Ordovician time, showing Ordovician rocks reconstructed into tectonic-stratigraphic belts.

Paleozoic volcanic rocks are present west of the carbonate platform and accretionary prism. This prescient cross section was published in 1978 by the USGS; it has almost all the elements of this story, including the Volcanic Island Arc to the west. The only thing it lacks is a drawing of a west dipping subduction zone under the arc. It was compiled from the locations of Paleozoic volcanic rocks in Nevada and eastern California. 


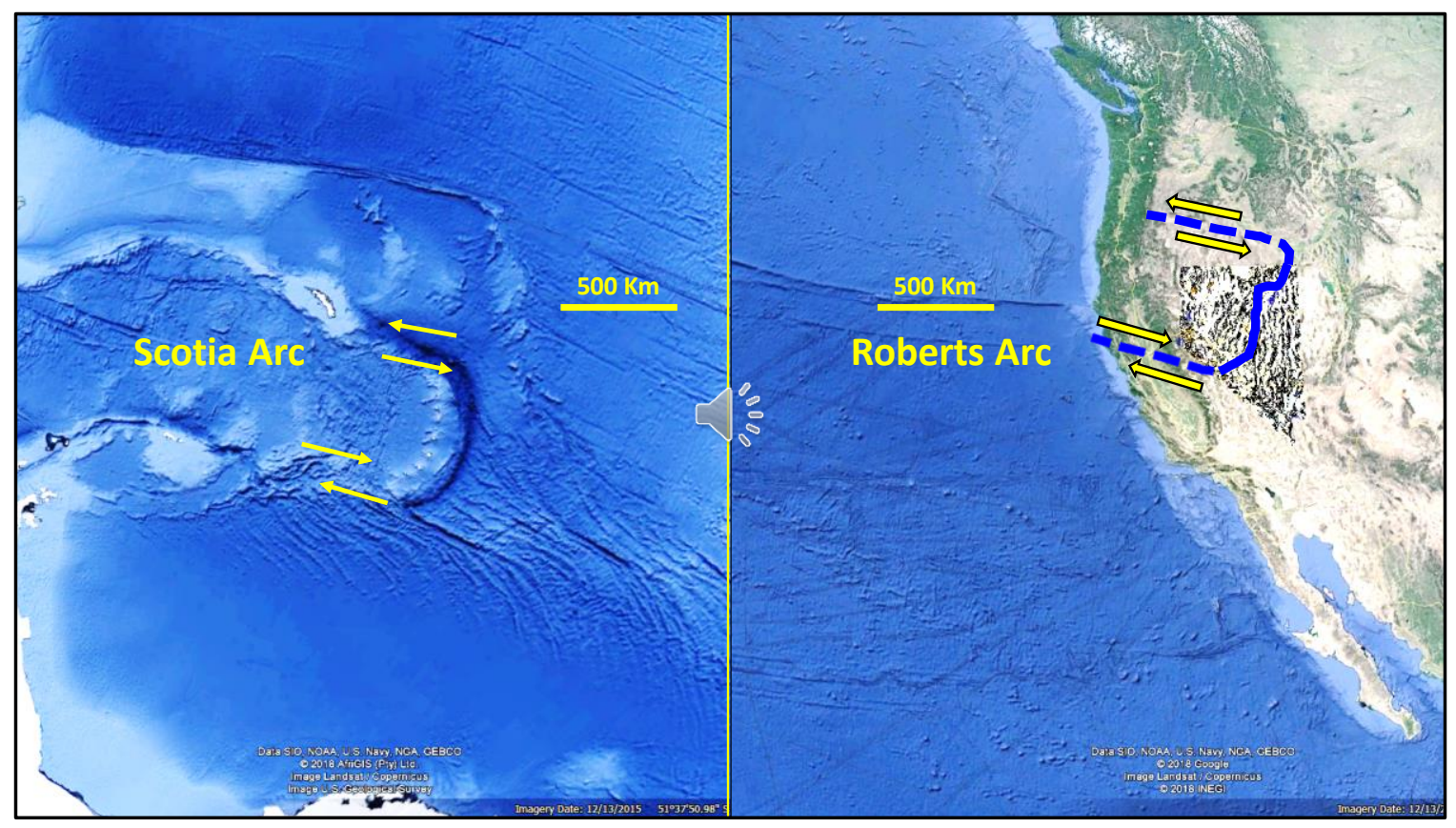

In summary, Jess Johnson proposed this model in 1981. The technology of that age limited his ability to point to plate tectonic analogs. I hope that Jess would have enjoyed seeing these Recent examples. 


\section{Thanks to: Mike Murphy, Stan Finney, Ted McKee, Jon Matti, David Jessup, Peter Baillie}

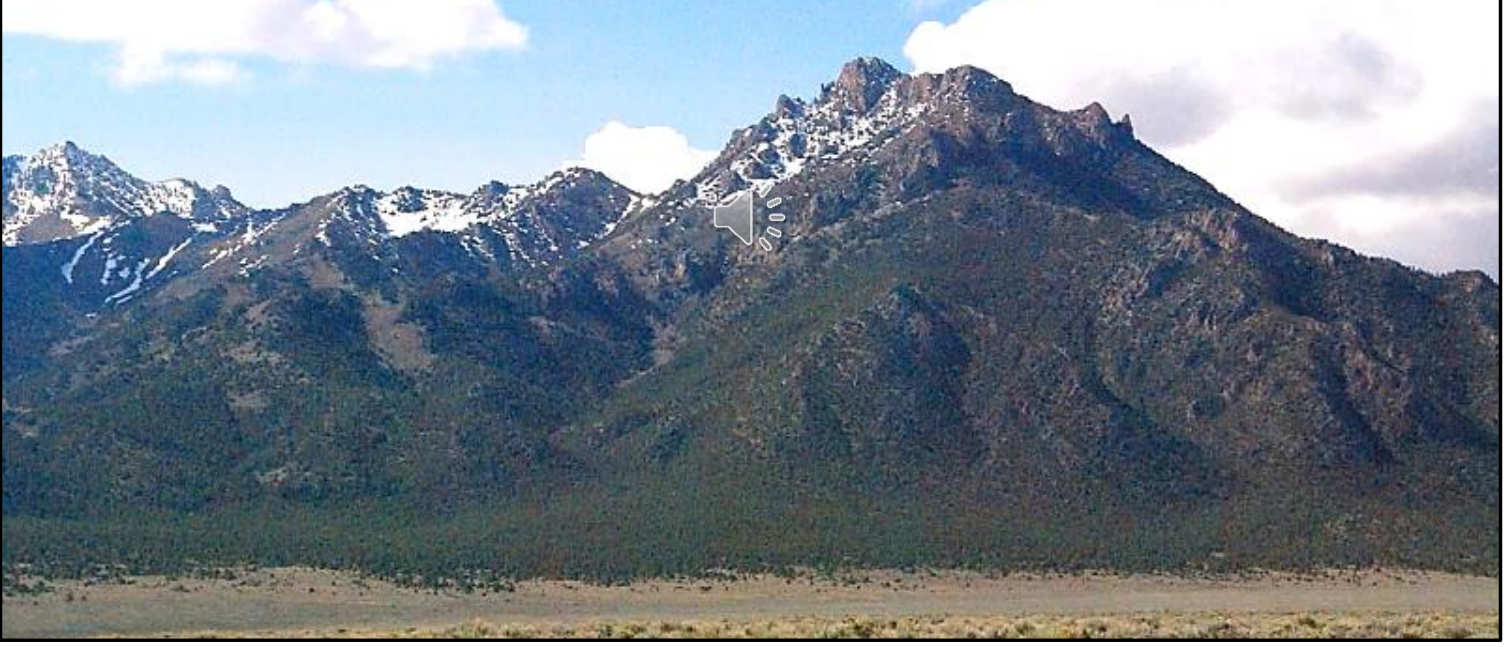

- I want to acknowledge the research efforts of these geologists. Professor Mike Murphy specialized in field mapping, biostratigraphy and sedimentology of lower plate carbonates in the Roberts Mountains. Professor Stan Finney worked to unravel the imbrication and ages of the Roberts Mountains upper plate. Ted McKee was the lead USGS mapper of the 15-minute Roberts Creek Mountain Quadrangle, assisted by Jon Matte of the USGS. David Jessup and Peter Baille interpreted Indonesian and Australian seismic data. My thanks to all of them. 


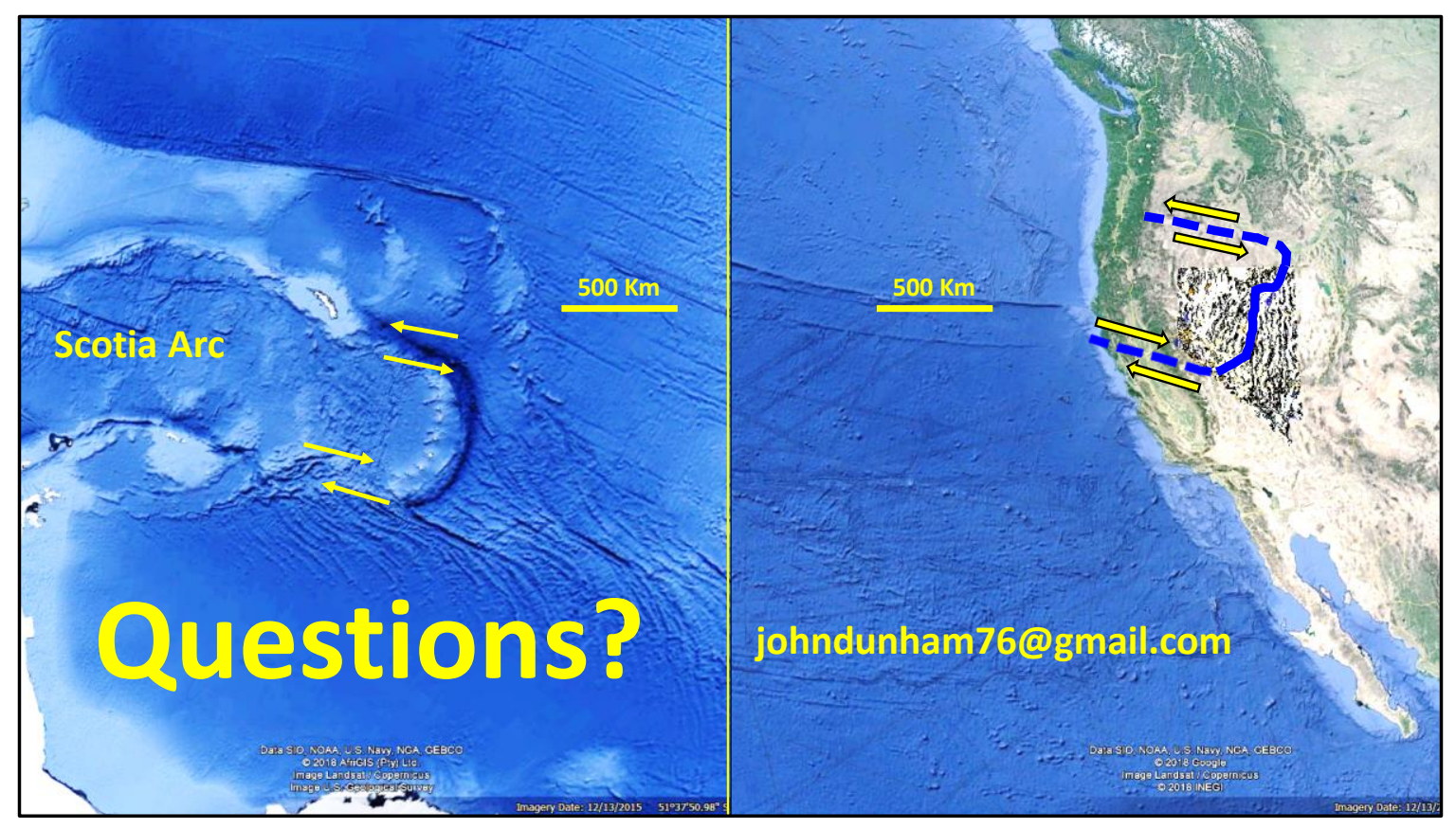

Questions 
References Cited on Slides:

\begin{tabular}{|c|c|c|}
\hline Slide & Topic & Reference \\
\hline 5 & Geologic Map of Nevada & Stewart, 1980, The Geology of Nevada - a discussion to accompany the Geologic Map of Nevada: Nevada Bureau of Mines and Geology Special Publication 4, $136 \mathrm{p}$. \\
\hline 10 & Japan Coseismic Displacement & Caltech - JPL ARIA group, 2011: http://www.tectonics.caltech.edu/slip_history/2011_taiheiyo-oki/ \\
\hline 10 & Slab Rollback & $\begin{array}{l}\text { Niu, Y., 2014, Geological understanding of plate tectonics: Basic concepts, illustrations, examples and new perspectives: Global Tectonics and Metallogeny v. 10, p. 23- } \\
\text { 46, DOI: 10.1127/gtm/2014/0009, https://dro.dur.ac.uk/15761/1/15761.pdf?DDD15+dgl0yn+d700tmt }\end{array}$ \\
\hline 11 & Marianas Trench Migration & $\begin{array}{l}\text { Andikagumi, H., Macpherson, C.G., and McCaffrey, K.J.W., 2020, Upper plate stress controls the distribution of Mariana Arc Volcanoes: Journal of Geophysical } \\
\text { Research Solid Earth vol. 125, no. 2, p. 1-27, https://doi.org/10.1029/2019JB017391 }\end{array}$ \\
\hline 14 & Timor Trough & $\begin{array}{l}\text { Baillie, P., Carter, P., and Duran, P.M., 2019, Evolution and Plays of the Banda Arc: AAPG Search and Discovery Article \#11245, DOI:10.1306/11245Baillie2019, } \\
\text { http://www.searchanddiscovery.com/documents/2019/11245baillie/ndx_baillie.pdf }\end{array}$ \\
\hline 14 & Continental Subduction & $\begin{array}{l}\text { Tate, G.W., McQuarrie, N., vanHinsbergen, J., Bakker, R., Harris, R., and Jiang, H., 2015, Australia going down under; quantifyng continental subduction during arc- } \\
\text { continent accretion in Timor-Leste: Geosphere, v. 11, no. 6, p. 1-24, doi:10.1130/GES01144.1 }\end{array}$ \\
\hline 16 & Timor Prism Imbricates & $\begin{array}{l}\text { Baillie, PI, Carter, PI, and Duran, P.M., 2019, Evolution and Plays of the Banda Arc: AAPG Search and Discovery Article \#11245, DOI:10.1306/11245Baillie2019, } \\
\text { http://www.searchanddiscovery.com/documents/2019/11245baillie/ndx_baillie.pdf }\end{array}$ \\
\hline 17 & Timor Trough & Darman, H., 2012, Timor Sea - Chapter 11 of Seismic Atlas of SE Asian Basins: http://geoseismic-seasia.blogspot.com/search/label/11\%20Timor\%20Sea \\
\hline 18 & $\begin{array}{l}\text { Timor Trough compared to } \\
\text { Antler Allochthon }\end{array}$ & $\begin{array}{l}\text { Silberling, N.J., Nichols, K.M., Trexler, J.H., Jewell, P.W., and Crosbie, R.A., 1997, Overview of Mississippian Depositional and Paleotectonic History of the Antler } \\
\text { Foreland, Eastern Nevada and Western Utah: BYU Studies in Geology v. 42, part 1, p. 161-196. }\end{array}$ \\
\hline 19 & Australian Subduction & $\begin{array}{l}\text { Saqab, M.M., 2016, Stratigraphic and tectonic evolution of the northwestern Bonaparte Basin (North West Shelf of Australia) during the Neogene: Ph.D. Dissertation, } \\
\text { The University of Western Australia, } 313 \text { p. } \\
\text { repository.uwa.edu.au/files/9673377/Thesis_Saqab_M.M._2016.pdf }\end{array}$ \\
\hline 22 & $\begin{array}{l}\text { Overlap of Allochthon above } \\
\text { Paleozoic Carbonate Platform }\end{array}$ & Stewart, 1980, The Geology of Nevada - a discussion to accompany the Geologic Map of Nevada: Nevada Bureau of Mines and Geology Special Publication 4, $136 \mathrm{p}$. \\
\hline 26 & $\begin{array}{l}\text { Roberts Mountains imbricate } \\
\text { thrusts }\end{array}$ & $\begin{array}{l}\text { Noble, P.J., and Finney, S.C., 1999, Recognition of fine-scale imbricate thrusts in lower Paleozoic orogenic belts - an example from the Roberts Mountains allochthon, } \\
\text { Nevada: Geology, v. 27, no. 6, p. 543-546. }\end{array}$ \\
\hline 27 & $\begin{array}{l}\text { Paleogeographic location of } \\
\text { allochthonous sediments }\end{array}$ & $\begin{array}{l}\text { Sheets, H., Mitchell, C., Melchin, M., Loxton, J., Storch, P., Carlucci, K., and Hawkins, A, 2016, Graptolite community responses to global climate change and the Late } \\
\text { Ordovician mass extinction: Proceedings of the National Academy of Sciences (PNAS), v. 113, no. 30, p. 8380-8385, } \\
\text { http://www.pnas.org/cgi/doi/10.1073/pnas.1602102113 }\end{array}$ \\
\hline 30 & Slabs sink to base of Mantle & $\begin{array}{l}\text { Brandenburg, J.P., Hauri, E., vanKeken, P., and Ballentine, C., 2008, A multiple-system study of the geochemical eolution of the mantle with force-balanced plates and } \\
\text { thermochemical effects: Earth and Planetary Science Letters v. 276, p. 1-13, doi:10.1016/j.epsl.2008.08.027 See also: Plank, T., and vanKeken, P., 2008, The ups and } \\
\text { downs of sediments: Nature Geoscience, v. 1, p. 17-18. https://doi.org/10.1038/ngeo.2007.68 }\end{array}$ \\
\hline 32 & Original Jess Johnson Model & $\begin{array}{l}\text { Johnson, J.G., and Pendergast, A., 1981, Timing and mode of emplacement of the Roberts Mountains allochthon, Antler orogeny: Geological Society of America } \\
\text { Bulletin, v. 92, p. 648-658. }\end{array}$ \\
\hline 34 & \begin{tabular}{|l} 
Paleozoic Volcanic Rocks of \\
Nevada
\end{tabular} & $\begin{array}{l}\text { Wruckle, C.T., Churkin, M., and Heropoulos, J., 1978, Deep-sea origin of Ordovician pillow basalt and associated sedimentary rocks, northern Nevada: Geological } \\
\text { Society of America Bulletin, v. 89, p. 1272-1280. }\end{array}$ \\
\hline 36 & $\begin{array}{l}\text { Roberts Creek Mountain } \\
\text { Quadrangle }\end{array}$ & $\begin{array}{l}\text { Murphy, M.A., McKee, E.H., Winterer, E.L., Matti, J.C., and Dunham, J.B., Geologic map of the Roberts Creek Mountain Quadrangle, Nevada: U.S. Geological Survey } \\
\text { Open-File report 78-376, https://doi.org/10.3133/ofr78376 }\end{array}$ \\
\hline
\end{tabular}

\section{References listed above}

